\title{
Local Government Protection of Biodiversity: What Is Its Niche?
}

\author{
A. Dan Tarlock $\dagger$
}

\begin{abstract}
Virtually all human activity in Travis County [Texas] has a direct or indirect impact on these rare or threatened species; thus everyone living in the study area bears some degree of responsibility for their current plight. With rare exceptions, no single private or public entity holds title to the land or has sole jurisdiction over a significant portion of the habitat of any single endangered species population in the Austin region. ${ }^{1}$
\end{abstract}

\section{Introduction: A Global Problem With Local Solutions?}

Second generation environmental protection policy has two basic objectives: the prevention and remediation of pollution risks and the promotion of biodiversity and sustainable development. ${ }^{2}$ In many cases, these objectives may overlap. Irrigation drainage that contaminates a wetland is an example of toxic pollution which also threatens biodiversity. ${ }^{3}$ However, the two objectives require

$\dagger$ Professor of Law, IIT Chicago-Kent College of Law. The research for this article was funded by the Marshall T. Ewell Fund of the Chicago-Kent College of Law and I gratefully acknowledge the support of Dean Richard Matasar. I owe a great debt of gratitude to my colleague Fred Bosselman, who shared his encyclopedic knowledge of land use law and practice with me, provided encouragement and constructive criticism, and was a constant source of up-to-date and difficult to locate information about ongoing biodiversity protection programs. I also wish to thank John Hart Ely, Distinguished Visiting Professor of Law, Fall, 1992, who generously shared his penetrating understanding of constitutional law and many other things with me during his visit. Finally, I thank my secretary, Ms. Anne Barrett, IIT Chicago-Kent College of Law Class of 1995, who worked wonders with the law school's computer network to citecheck my drafts and to master the University of Chicago Style Manual.

1 Balcones Canyonlands and Conservation Plan Appendices, Comprehensive Report of the Biological Advisory Team 3 (Final Draft February 1992).

2 Professor Donald T. Hornstein identifies two basic paradigms as environmental protection enters its third decade: risk-oriented reform and cause-oriented reform, which shifts emphasis away from after-the-fact "pollution control," and "toward more direct incentives for less polluting production processes or product design." Donald T. Hornstein, Paradigms Lost and Found in Environmental Law Reform: Lessons From Federal Pesticide Regulation For Integrating Science, Politics, And Sustainability, 10 Yale J Reg 369, 382 (1993).

3 The discovery that irrigation run-off from farms in California's San Joaquin Valley increased selenium concentrations in the Kesterson National Wildlife Refuge focused public 
fundamentally different regulatory approaches. The first generation of environmental protection programs concentrated on toxic risk reduction because of political pressure and its amenability to New Deal command and control regulation. ${ }^{4}$ More site-specific and politically controversial objectives such as biodiversity protection and sustainable development were slighted as cancer risk became a proxy for environmental harm. ${ }^{5}$ The politics of environmental protection are changing, ${ }^{6}$ and the second generation of environmental regulation will have to give equal or greater weight to these neglected problems as evidence mounts on the central importance of biodiversity to the core utilitarian objectives of protecting human health and welfare. ${ }^{7}$ This shift in emphasis will place new environmental protection responsibilities and opportunities on local governments, the front line resource management units. ${ }^{8}$

attention on this endemic threat to wildlife habitats and populations. See Committee on Irrigation-Induced Water Quality Problems, Water Science and Technology Board, National Research Council, Irrigation-Induced Water Quality Problems: What Can Be Learned from the San Joaquin Valley Experience 46-48 (National Academy Press, 1989).

An even more tragic example is the Chelyabinsk region of Russia, the center of plutonium production in the former U.S.S.R. during the Cold War. Nuclear wastes were dumped into the Techa River until the early 1950s, and in 1957 a tank of radioactive waste exploded at a weapons plant. The resulting radioactive contamination is a continuing public health and ecological disaster. A recent review of the meager information about Chelyabinsk reports that the Soviets designated 17,000 acres of contaminated area as a zapovednik (nature preserve), but all the pine trees in the area died because pines are sensitive to radiation. Today, the area is filled with radiation warning signs. Scott D. Monroe, Chelyabinsk: The Evolution of a Disaster, 33 Post-Soviet Geography 533 (1992).

- James E. Krier, The Pollution Problem and Legal Institutions: A Conceptual Overview, 18 UCLA L Rev 429, 461 (1971).

- See Donald T. Hornstein, Reclaiming Environmental Law: A Normative Critique of Comparative Risk Analysis, 92 Colum L Rev 562 (1992) (overview of risk-based analysis). See also Clayton P. Gillette and James E. Krier, Risk, Courts, and Agencies, $138 \mathrm{U}$ Pa L Rev 1027, 1070-85 (1990).

- Philip Shabecoff traces the expanding agenda of the American environmental movement from an almost exclusive focus on toxic pollution to a multi-objective national and international agenda. Philip Shabecoff, A Fierce Green Fire: The American Environmental Movement (Hill \& Wang, 1993).

7 The current concern over decreasing North American frog populations illustrates how little we know about the possible adverse consequences of ecosystem modification. Frog and toad populations are declining all over the continent, yet scientists disagree about the causes, beyond habitat destruction, as well as about the lessons to be drawn from the existing data. Nonetheless, many ecologists are concerned with both short term costs, such as increased disease-bearing insect populations, and the long term loss of ecosystems as a crucial link in the food chain is removed or radically reduced. See Emily Yoffe, Silence of the Frogs, The NY Times Magazine 36, 76 (Dec 13, 1992).

s Current thinking about the relationship between global warming and biological diversity illustrates the role that local governments may play in responding to these problems. If projected temperature rises actually occur, life-zone boundaries in Florida may move 300 $\mathrm{km}$ north, placing many already stressed species and plant communities at great risk. To 
Biodiversity protection is more difficult to achieve than toxic risk reduction, because the politics of biodiversity protection are infinitely more complex than the politics of pollution. Pollution risk prevention and remediation involve the application of technology to specific industrial activities or the removal of chemical products from the market. Pollution control is highly centralized; the federal government formulates technology-forcing standards and the states implement them. ${ }^{9}$ The costs of achieving these objectives can be spread widely among taxpayers and consumers.

Biodiversity protection, in contrast, is becoming more decentralized and site-specific. ${ }^{10}$ With some exceptions, the control of land use remains with local units of government-cities, counties and special districts. ${ }^{11}$ To protect biodiversity, we rely on planning and the regulation of land and water development to deflect harm-

give these species a fighting chance to adapt, various state and local conservation strategies must be tried, including inter-reserve corridors, streamside buffer zones, reserve buffer zones, and land banks. Larry D. Harris and Wendell P. Cropper, Jr., Between the Devil and the Deep Blue Sea: Implications of Climate Change for Florida's Fauna, in Robert L. Peters and Thomas E. Lovejoy, eds, Global Warming and Biological Diversity 309, 313, 319-22 (Yale, 1992).

- For a critical analysis of centralized pollution control regulation, see Richard B. Stewart, Pyramids of Sacrifice? Problems of Federalism in Mandating State Implementation of National Environmental Policy, 86 Yale L J 1196, 1199-1202 (1977).

${ }^{20}$ Biodiversity protection initially focused on endangered species on public lands. These controversies remain extremely important, but as our understanding of biodiversity protection increases, we realize that all categories of land must be protected. This is the conclusion of the recently issued Report of the National Commission on the Environment, Choosing a Sustainable Future 113-30 (Island, 1993). For a passionately argued example of this insufficiency, see Alston Chase, Playing God in Yellowstone, 363-68 (Atlantic Monthly Press, 1986). Local influence is strong despite the breadth of power to manage these lands conferred by federal and state authority. As proprietors and sovereigns, the federal government and the states (for state lands) have the power to preempt local control and regulate private land uses that threaten to degrade these lands. See text accompanying notes 69-100. The reality is more complex, for federal and state land use managers are extremely deferential to local concerns. See Sally K. Fairfax, Jon A. Souder, and Gretta Goldenman, The School Trust Lands: A Fresh Look at Conventional Wisdom, 22 Envir L 797, 866-67 n 271 (1992). The High Country News is filled with stories of local commodity users successfully influencing federal land management policy. See, for example, Ed Marston, Moab BLM Marches to a Southern Utah Beat, 10 High Country News 26, 1 (Jun 10, 1992). Local governments in the West expend considerable effort to develop land use plans that can be used to counter federal environmental protection mandates. For example, Catron County, New Mexico recently adopted a land use plan which declares that commodity production is deeply rooted in the county's "custom and culture," Don't Mess With Us, Say These Westerners, 58 Planning 28 (Nov 1992), which is now being taken seriously by the Department of Interior, as a way of promoting more environmentally sensitive grazing practices and thus stabilizing a threatened rural economy. Keith Schneider, In Cattle-Raising West, a County Wants to Help U.S. Manage Federal Lands, NY Times A14 (May 6, 1993).

11 Holly Doremus, Patching The Ark: Improving Legal Protection of Biological Diversity, 18 Ecol L Q 265, 288-89 (1991). 
ful activities from sensitive lands and related water resources, followed by intensive site management. This is not easy, as units of local government must live with jurisdictional boundaries that do not correspond to the scientific imperatives of habitat protection. ${ }^{12}$ To further complicate the problem, local controversies are more intense and less subject to countervailing forces. The cost sharing base for biodiversity protection is narrower than other types of environmental regulation, such as regulations that force industrywide technological innovation. Finally, the potential interference with private property is greater for programs that focus on individual landowners than for programs designed to curb air and water pollution. The numerous recent reports that landowners have destroyed species or critical habitats to avoid compliance with the Endangered Species Act is symptomatic of this problem. ${ }^{13}$

Biodiversity protection is a new chapter in the dramas of public land management and urban development in America. ${ }^{14}$ To develop this country, we have destroyed or manipulated the natural environment for commodity production and urban development. ${ }^{15}$ Ever since the Civil War, the distinctive feature of American urban development has been deconcentration. The consumption of agricultural or undeveloped land reflected the American dream of individual autonomy and self-fulfillment. ${ }^{16}$ Until the 1960 s, land use law functioned primarily to set the minimum ground rules for lowdensity suburban development. Land use planners have long attempted to blunt the market preference for uniform low-density

12 The "interactive" relationship between the geographical landscape, which focuses on the scale and function of the spatial distribution of physical and cultural phenomena, and the legal landscape is explored in Rutherford H. Platt, Land Use Control: Geography, Law, and Public Policy 18-37 (Prentice Hall, 1991).

${ }^{13}$ Maura Dolan, Nature At Risk in A Quiet War, LA Times A1 (Dec 20, 1992).

${ }^{14}$ Biodiversity protection can build on a thirty-year tradition of local environmental regulation, see, for example, Brian J. L. Barry, et al, Land Use, Urban Form and Environmental Quality 89-92 (University of Chicago Dept of Geography, 1974), but the concept poses fundamental challenges to resource managers, land use planners, and regulators. Colin Rankin and Michael M'Gonigle, Legislation for Biological Diversity: A Review and Proposal for British Columbia, 25 U Brit Colum L Rev 277 (1991), is a good exploration of the challenges that biodiversity protection poses for traditional legal and scientific approaches to public resource management.

1s See William Cronon, Nature's Metropolis: Chicago and the Great West xiii (Norton, 1991) and Joseph L. Sax, Ecosystems and Property Rights in the Greater Yellowstone, in Robert B. Keiter and Mark S. Boyce, eds, The Greater Yellowstone Ecosystem: Redefining America's Wilderness Heritage 77 (Yale, 1991).

${ }^{16}$ The most comprehensive analysis of the dynamics of suburban growth is Kenneth T. Jackson, Crabgrass Frontier: The Suburbanization of the United States (Oxford, 1985). For an earlier history with a more central city focus, see Sam Bass Warner, Jr., The Urban Wilderness: $A$ History of the American City (Harper \& Row, 1972). 
development ${ }^{17}$ with an alternative communitarian vision of higher density residential and commercial clusters in closer contact with nature. Ebenezer Howard's Garden Cities of Tomorrow ${ }^{18}$ has had a profound influence on American thinking about suburban density and the proper balance between developed and open land. ${ }^{19}$ The idea of villages surrounded by open space fits with a longstanding Romantic preference for the country over the city, ${ }^{20}$ and provided the intellectual framework for efforts-beginning in the mid1960s-to limit the last stages of post-World War II suburbanization.

This idea continues to influence local government efforts to integrate environmental protection and land use regulation. In the 1970s, growth management emerged as a major land use issue in response to both environmental pressures and the inability of local governments to provide services in advance of development from conventional sources of local revenue. Growth control programs promoted open space preservation by reducing densities in semirural areas, allowing developers to compete for the available alloca-

17 American theories of urban form were developed by the "Chicago School" of urban sociology. Harvey Zorbaugh developed the solar model to explain the cycle of outward expansion of cities in response to the automobile. Harvey W. Zorbaugh, The Gold Coast and the Slum 230 (Chicago, 1929). Most land use scholarship is concerned with moderating the pace of suburban or exurban development, see, for example, Urban Land Institute, 1-5 Management \& Control of Growth (1975-1980), or with the fate of the nineteenth century industrial and distribution cities drained by the twentieth century suburban exodus, see, for example, Paul E. Peterson, ed, The New Urban Reality (Brookings Institution, 1985).

ts Ebenezer Howard, Garden Cities of Tomorrow (MTT, 1965).

19 David C. Thorns, The Quest for Community: Social Aspects of Residential Growth 28-34 (Wiley, 1976) (exploring the convergence and divergence between the Garden City movement and American suburban growth).

20 The widespread antipathy of many American intellectuals, starting with Thomas Jefferson, toward cities has had two contradictory strains. One is the Romantic notion that closeness to nature is divine, and the other is the anti-Romantic American inferiority complex which compared our raw cities with Europe's centers of civilization. See Morton and Lucia White, The Intellectual Versus the City: From Thomas Jefferson to Frank Lloyd Wright 31, 75 (Oxford, 1977). In an early essay, the great German cultural historian Carl E. Schorske traced the transition from the Enlightenment view of the city as place of virtue to the 19 th century view of the city as center of vice. The Idea of the City in European Thought: Voltaire to Spengler, in Oscar Handlin and John Burchard, eds, The Historian and the City 95 (MIT, 1963). 
tion of building permits, ${ }^{21}$ and trying to firm up boundaries between urban and non-urban areas. ${ }^{22}$

Current local government efforts to protect biodiversity are an extension of the suburban growth control movement, ${ }^{23}$ but there are crucial philosophical differences. Biodiversity protection is not a Romantic effort to create the illusion of a prior Eden, but is a highly rational effort to apply modern science to prevent further harmful reductions in high quality habitats and the species that they support. Scientific biodiversity protection is ultimately not based on immutable values, ${ }^{24}$ but on the constant interplay between theory and practice, and thus is subject to constant modification as new information is acquired.

This Article examines the paradoxes, problems, and opportunities local governments face in using their delegated regulatory authority to protect biodiversity. ${ }^{25}$ The source of the problems that local governments will confront lies in the paradox between the grass roots origins of environmentalism ${ }^{26}$ and the limited role actually assigned to local governments. From the late 1960s to the 1980 s, the appropriate level of government response was perceived

21 For example, Livermore, California, a rapidly growing suburb on the eastern edge of the Greater San Francisco Bay Area, has a maximum yearly allowable growth rate of 3.5\%. Proposed developments are evaluated by non-numeric criteria which include landscaping and open space dedications. Richard T. LeGates, The Emergence of Flexible Growth Management Systems in the San Francisco Bay Area, 24 Loyola LA I Rev 1035, 1064-67 (1991).

${ }^{22}$ San Diego has a tiered growth management plan. Douglas R. Porter, Do State Growth Management Acts Make A Difference? Local Growth Management Measures Under Different State Growth Policies, 24 Loyola LA L Rev 1021-23 (1991). Such plans, a kind of less restrictive zoning, express "distinct intentions toward development" in designated areas and use various incentives to encourage the desired type of development in a given area. Id at 1020. The plan has four tiers: urbanized areas, planned urbanizing areas, future urbanizing areas, and open space. Id at 1021. But because of development in the first two tiers and a failure to delineate any fourth tier lands for fear of takings claims, San Diego's third tier, originally to be developed as urban areas expanded, has become the "sole vestige of treasured open space in the city." Id at 1021-22.

${ }^{23}$ William K. Reilly, ed, The Use of Land: A Citizens' Policy Guide to Urban Growth (Crowell, 1973) is an early influential study which articulated the connection between growth control, higher density residential development, and environmental protection.

24 See note 45 and accompanying text.

2s There are many non-regulatory and combined regulatory and non-regulatory governmental efforts underway to promote biodiversity. These include the restoration of native habitats on public park lands and urban wildlife management programs. For example, Cape Coral, Florida has increased its burrowing owl population by a combination of public education and limiting harmful construction activities to the non-nesting season. Don A. Wood, Brian A. Millsap, and Patrick M. Rose, Florida's Nongame and Endangered Species Programs, 9 Endangered Species Update 8, 9 (July/August 1992).

${ }^{28}$ Samuel P. Hays, Beauty, Health, and Permanence: Environmental Politics in the United States, 1955-1985 287 (Cambridge, 1987). 
to be the national or state level, and local approaches were often preempted ${ }^{27}$ or abandoned in the face of intense political opposition. ${ }^{28}$ In addition, the recent focus on local governments has been on municipal pollution liability rather than affirmative programs. Congress has seldom granted local governments immunity from federal environmental regulations, and localities are expected to conform their actions to federal and state environmental standards. ${ }^{28}$

Current interest in local biodiversity protection is the product of worldwide concern over the degradation of the global land base. This concern has increased our awareness of the interconnection between land use practices and environmental degradation..$^{30}$ Local governments in this country and throughout the world have begun to develop environmental programs to respond to international issues such as global warming and biodiversity protection. ${ }^{31}$ For example, in 1990, municipal officials from forty-four countries met at the United Nations to form an International Council for Local Environmental Initiatives. ${ }^{32}$

Local governments have considerable but incomplete authority to promote biodiversity as compared to pollution control. Biodiversity is not yet an organizing concept for federal or state regulatory programs, so local governments have discretion to define their regulatory niche. Local governments operate in a hierarchy of interna-

${ }^{27}$ For example, many states preempted local authority to decide whether or not to accept hazardous waste treatment, storage, and disposal facilities. See Arden H. Rathkopf and Daren A. Rathkopf, The Law of Zoning and Planning § 7A.06[3] (Clark Boardman, 1987 \& Supp 1990). Illinois remains a major exception. See Laurie Reynolds, The Failure of Local Landfill Siting Control in Illinois, 17 SIU L J 1 (1992); Ill Stat Ann ch 111 1/2, § 1039.2 (Smith-Hurd 1991).

${ }^{23}$ See Daniel R. Mandelker and Susan B. Rothschild, The Role of Land-Use Controls in Combating Air Pollution Under the Clean Air Act of 1970, 3 Ecol L Q 235, 241-42 (1973).

20 See US Advisory Commission on Intergovernmental Relations, Intergovernmental Decisionmaking for Environmental Protection and Public Works, No A-122 at 1-3, 64-67 (Nov 1992), for review of the problems that units of local government face in complying with federal environmental mandates.

so See D.T. Kuzmiak, The American Environmental Movement, 157 Geographical J 265, 276 (1991).

31 A recent environmental conference of European municipal experts focused, inter alia, on the role of European cities as markets for rain forest products and on the problem of habitat destruction from "the continuing process of changes in land-use and uncontrolled urban growth, in combination with acidification [which] also reduces global biological diversity." Tjeerd Deelstra, Cities and the Global Environment in Tjeerd Deelstra, ed, Cities and the Global Environment 33, 36 (European Foundation for the Improvement of Living and Working Conditions, 1991).

32 5 United Nations Environment Programme, North American News 4 (Oct 1990). 
tional, federal, and state environmental protection regimes which both constrain and encourage local initiatives, but the novelty of biodiversity protection means that jurisdictional lines have not hardened. With the exception of the Endangered Species Act, federal and state mandates seldom impose biodiversity protection duties equal to the pollution control duties imposed by federal and state law.

Local governments face a major problem in devising biodiversity protection initiatives in the "regulatory gap" between the scientific imperatives of biodiversity protection and the limitations on local government in terms of its regulatory powers, geographical scope, and historic incentives. Local authority must be patched together from existing delegations of authority to address environmental and related land use issues, and must counter the reality that local governments need to attract land use development to survive. ${ }^{33}$ Our traditional suburban Social Darwinism and the limited geographical scale of local governments create few incentives for them to consider any but the most immediate and short-term external costs of land development. Biodiversity protection, in contrast, requires local governments to restrain land development in specific landscapes ${ }^{34}$ and to coordinate their activities. with other units in a biological region.

Achieving coordination will be difficult, because the scale of local land use regulation is dictated by the artificial jurisdictional boundaries drawn by state law; the proper scale of biodiversity protection is the relevant ecosystem. Balkanization aptly describes local governments in the United States, and the consequent expectations of quasi-local sovereignty will impede biodiversity protection. The reaction of local planning officials in New York State to a New York Court of Appeals decision, which refused to mandate a judicial regional biodiversity protection process but called for state legislative action to develop a regional planning process, ${ }^{35}$ exemplifies the United States' failure to develop effective metropolitan coordination mechanisms. ${ }^{36}$ The executive director of the Suffolk

\footnotetext{
"3 Vicki Been, "Exit" As A Constraint on Land Use Exactions: Rethinking the Unconstitutional Conditions Doctrine, 91 Colum L Rev 473, 511-28 (1991) (surveys the literature on inter-municipal competition for new residents).

s4 See generally Wendy E. Hudson, ed, Landscape Linkages and Biodiversity (Island, 1991).

${ }^{35}$ Long Island Pine Barrens Society, Inc. $v$ Planning Board of Town of Brookhaven, 80 NY2d 500, 591 NYS2d 982, 990 (1992).

so There are many reasons for the failure of the metropolitan government movement. Despite eloquent pleas for judicial metropolitan doctrines, courts have failed to intervene.
} 
County Regional Planning Board explained why state legislative action to implement the Court's suggestion is unlikely: "New York State would have to rewrite town law and municipal law, and take town powers and zoning board powers away from the towns and villages and give it to a regional entity .... That position would go over like a lead balloon. It has minus zero chance of working."

This Article focuses on four aspects of the legal framework for local biodiversity protection. Section I examines the scientific case for biodiversity protection and the land management principles advocated by the newly emerging discipline of conservation biology. Section II describes current international and federal biodiversity protection regimes with emphasis on the role of local governments in these regimes. Section III analyzes the sources of local power to protect biodiversity and limitations on this power. Section IV examines the major constraints on local biodiversity protection: the constitutional prohibition against taking private property without just compensation, statutory and judicial restraints on the use of exactions to finance reserves acquisitions, and state and federal preemption. Section V briefly explores several promising local protection initiatives and offers a tentative assessment of their likely effectiveness. Beyond charting this important new development in local government law, my principal argument asserts that it is difficult but possible to integrate the "imperatives" of biodiversity protection with the protection of individual rights within the framework of federal constitutional law and local government regulatory authority.

\section{The Scientific Rationale for Biodiversity Protection}

Biodiversity is a recent descriptive and normative construct which emerged in the 1980s to give a more precise focus to a number of environmental, resource management, and agricultural programs. ${ }^{38}$ Lawyers need to understand this concept because it will inform how local governments will exercise their delegated police

See, Michael H. Feiler, Metropolitanization and Land-Use Parochialism-Toward A Judicial Attitude, 69 Mich L Rev 655, 708 (1971); Note, Zoning for the Regional Welfare, 89 Yale L J 748, 757-63 (1980).

37 Sarah Lyall, Court Clears Way for Building on Pine Barrens of Long Island, NY Times A1, A11 (Nov 25, 1992).

3a The first major United States government office to use this lens to examine existing environmental protection and related regimes was the Office of Technology Assessment. See United States Congress, Office of Technology Assessment, Technologies To Maintain Biological Diversity (1987). 
power and how courts will review their efforts. The following summarizes the accepted scientific definitions of the term:

"Biological diversity" encompasses all species of plants, animals, and microorganisms and the ecosystems and ecological processes of which they are parts. It is an umbrella term for the degree of nature's variety, including both the number and frequency of ecosystems, species, or genes in a given assemblage. It is usually considered at three different levels: genetic diversity, species diversity, and ecosystem diversity. ${ }^{38}$

This Article focuses on the third and highest level, ecosystem diversity. To many, it is the most important ${ }^{40}$ and it is the conception which can guide local governments in implementing biodiversity policy.

Biodiversity is replacing the two major resource use paradigms-scientific conservation and preservation-on which we have relied to manage natural resources. The concept is scientific, philosophical, and regulatory because it attempts to unify a wide range of physical sciences and environmental ethics ${ }^{41}$ for a social objective, although it is not yet fully operational. ${ }^{42}$ Biological diversity draws both from classic ecology and from new scientific thinking that views nature as based on constantly interacting and altered systems. Ecologists have shed the static models of stable, balanced ecosystems in favor of a more complex view of systems continuously changing in response to human intervention. The objective is not to insulate them from human activity in the traditional sense, but to monitor and manage them to "avoid making novel kinds of changes and imposing rates of change at each level of the biosphere that exceed the ability of life to respond to

38 Jeffrey A. McNeely, et al, Conserving The World's Biological Diversity 17 (International Union for Conservation of Nature and Natural Resources, 1990).

40 See, for example, Edward O. Wilson, The Diversity of Life 336 (Harvard, 1992).

41 The growing field of environmental ethics has collapsed the traditional dichotomy between fact and value to impute value to natural systems as well as humans. See, for example, Bryan G. Norton, Why Preserve Natural Variety? 46-72 (Princeton, 1987).

42 Gary D. Meyers, Surveying the Lay of the Land, Air, and Water: Features of Current International Environmental and Natural Resources Law, and Future Prospects for the Protection of Species Habitat to Preserve Global Biological Diversity, 3 Colo J Int Envir L \& Pol 479, 548-73 (1992). For the past four years, Congress has refused to enact legislation authorizing and funding a national center for biological diversity, but the Vice President of the Smithsonian Institution and a leading proponent of biodiversity protection, Thomas J. Lovejoy, has predicted that a center will be created in 1993. BNA, Biodiversity: U.S. Will Create Biodiversity Center Within Year, Smithsonian Official Says, Daily Report for Executives (Nov 9, 1992). 
them." 4 A leading conservation biologist has posited the idealistic goal of biodiversity protection as the "restoration and preservation of presettlement type ecosystem structure, function, and integrity," but adds "this does not mean trying to hold nature steady but rather maintaining natural dynamics and discouraging anthropogenic deterioration." 44

Biodiversity protection has been analyzed and justified from a wide variety of scientific and ethical perspectives. ${ }^{45}$ This Article assumes that biodiversity is a societal objective of uncertain weight which can be justified primarily as an insurance policy against future catastrophes ${ }^{46}$ and which consists of the development of new social institutions to conserve the planet's biological resources. A typical statement of this conservation objective imposes a duty on states to "maintain maximum biological diversity by ensuring the survival and [p]romoting the conservation on their natural habitat of all species of fauna and flora, in particular those that are rare, endemic or endangered."47 As Edward Wilson has written: "Great biological diversity takes long stretches of geological time and the accumulation of large reservoirs of unique genes. The richest ecosystems build slowly, over millions of years. ... Such a creation is part of deep history, and the planet does not have the means nor we the time to see it repeated." 48

At the present time, individual species protection serves as a proxy for biodiversity protection, but like all proxies, it is crude. Our current focus on selected species extinction, especially on large, popular mammals, has rightly been criticized because it neglects the need for ecosystems that function over wide spatial

48 Daniel B. Botkin, Discordant Harmonies: A New Ecology for the Twenty-first Century 181 (Oxford, 1990).

“ Reed F. Noss, Protecting Natural Areas in Fragmented Landscapes, 7 Natural Areas J 2, 4 (1987). For a detailed explanation of the criteria being developed to select protected areas, see Linda C. Duever and Reed F. Noss, A Computerized Method of Priority Ranking for Natural Areas, in Ecosystem Management: Rare Species and Significant Habitats, 471 New York State Museum Bulletin 22 (1990).

${ }^{45}$ The leading collection of essays on the different perspectives is Edward O. Wilson, ed, Biodiversity (National Academy Press, 1988).

48 Wilson, The Diversity of Life (cited in note 40 ) is the most comprehensive and persuasive case for biodiversity protection.

${ }^{47}$ World Commission on Environment and Development, Legal Principles For Environmental Protection and Sustainable Development, reproduced in Edith Brown Weiss, Daniel Barstow Magraw, and Paul C. Szasz, International Environmental Law: Basic Instruments and References 189 (Transnational Publishers, 1992).

'B Wilson, The Diversity of Life at 74 (cited in note 40). 
ranges, rather than small islands of protected wildlife. ${ }^{4 \theta}$ Although the two concepts are closely linked in that indicator species are seen as a reliable means to gauge the health of an ecosystem, biodiversity protection is much broader than species protection. "Species counts are useful because the species is a fairly concrete and readily defined measure of genetic uniqueness. But many evolutionary questions or practical purposes direct a researcher's interest toward diversity at higher or lower taxonomic levels."

This new ecology is the basis of a rapidly growing applied regulatory science, ${ }^{51}$ conservation biology, which seeks to delineate and manage critical habitats.52 Conservation biology recognizes that land reserves equal to a species's habitat and range, or large enough for a complete ecosystem, are very difficult to construct on public lands ${ }^{53}$ and impossible where the majority of land is privately owned. Instead, this new applied science tries to retard the leading cause of extinction, habitat fragmentation and reduction, ${ }^{54}$ by cobbling together connected patches of habitat (taking into account existing political boundaries and land use patterns) to form a network of islands and corridors ${ }^{\mathrm{s5}}$ with adequate margins of safety for endangered and threatened species and ecosystems. ${ }^{.86}$

"See Douglas O. Linder, "Are All Species Created Equal?" And Other Questions Shaping Wildlife Law, 12 Harv Envir L Rev 157, 194-95 (1988).

${ }^{\text {so }}$ Robert M. May, How Many Species Inhabit the Earth?, Scientific American 42, 48 (Oct 1992).

${ }^{51}$ Starting in the 1970s, science policy analysts identified regulatory science as a new type of science, although the scientific community remains somewhat resistant to the concept. On one level, regulatory science is simply a new category of applied research because it investigates questions external to the researcher as opposed to "pure" science. However, there is an important difference: while applied science has historically responded to technical questions, environmental regulation also involves policy concerns. See Sheila Jasanoff, The Fifth Branch: Science Advisors as Policy Makers 76-79 (Harvard, 1990); Hornstein, 92 Colum L Rev 562 (cited in note 5).

${ }^{82}$ See generally Jon E. Rodiek and Eric G. Bolen, eds, Wildlife and Habitats in Managed Landscapes (Island Press, 1991).

${ }^{53}$ See generally Keiter and Boyce, eds, The Greater Yellowstone Ecosystem (cited in note 15).

B4 Bruce A. Wilcox and Dennis D. Murphy, Conservation Strategy: The Effects of Fragmentation on Extinction, 125 The American Naturalist 879, 884 (1985).

${ }^{B S}$ The focus on corridors between critical habitats is often cited as the rationale for preserving existing urban open spaces and close-in undeveloped areas. "Corridors and surrounding habitats are among the most valuable urban natural areas, providing for extensive biological diversity and reducing the isolation of the largest surviving ecosystems, which may be far from urban centers." Dennis D. Murphy, Challenges to Biological Diversity in Urban Areas, in Edward O. Wilson, ed, Biodiversity 71, 73 (National Academy Press, 1988).

${ }^{58}$ See Daniel Simerloff and Lawrence G. Abele, Refuge Design and Island Biogeographic Theory: Effects of Fragmentation, 120 American Naturalist 41 (1982); Michael E. Soulé, ed, Viable Populations for Conservation (Cambridge, 1987). The entire notion of a minimum viable population or minimum viable reserve area is extremely controversial to 
Conservation biology is a true paradigm shift in resource management. It rejects the traditional idea of resource preservation as fencing out humans to the maximum extent possible to isolate an ecosystem and replaces it with a view that recognizes the dynamic interaction between human settlement and natural systems. ${ }^{.7}$ To implement this concept, local governments are now coping with new criteria for drawing land use control lines. Biodiversity protection "zones" require the establishment of habitat units based on the biological productivity of the candidate site.

Current theories of the geographic scope of habitat units pose a challenge for local governments looking for the inevitable quick fix for biodiversity "problems." As the examples discussed in Section V illustrate, biodiversity protection is driven by federal and state endangered species laws. Most local governments see endangered species and related biodiversity issues as problems that must be quickly "solved" so that necessary development can proceed. The tendency is to set aside $a$ reserve and be done with it. However, conservation biology teaches that habitat units cannot exist in isolation from each other. A critical mass of contiguous units must be calculated; the corridors linking them and the edges of the units must be simultaneously delineated and mapped to develop a scientifically defensible biodiversity protection plan.

The concepts of conservation biology are not abstractions for many local governments. Localities are being required to implement these concepts in order to comply with federal mandates. As do all new land use regulatory programs, the implementation of conservation biology raises substantial questions of local government authority. The next Section deals with the federal mandates applicable to local governments and the existing authority that local governments can exercise to comply with these mandates.

scientists for two inconsistent reasons. First, scientists generally limit themselves to verifiable "positive" statements and eschew normative statements. Second, scientists willing to make normative statements argue that notions of minima will not promote robust and bountiful populations. The idea is defined and defended in Michael E. Gilpin and Michael E. Soulé, Minimum Viable Populations: Processes of Species Extinction, in Michael E. Soulé, ed, Conservation Biology: The Science of Scarcity and Diversity (Sinauer, 1986).

${ }^{57}$ See generally David Western and Mary C. Pearl, eds, Conservation for the TwentyFirst Century 31-130 (Oxford, 1989). See text at notes 155-227 for a discussion of the most ambitious effort to date to implement these ideas in the United States. 


\section{International and Federal Authority to Protect BIODIVERSITY}

International, federal, and state programs all support local biodiversity protection initiatives. Local governments have been delegated broad discretion to use the state's reserved police power to regulate land use. ${ }^{58}$ International and federal legislation can operate both to constrain local authority and to inform courts of the evolution of the police power. ${ }^{30}$ This Section sketches briefly the principal existing international and federal biodiversity protection duties.

\section{A. International Law}

Strictly speaking, nation-states do not have a duty under international law to protect biodiversity within their own borders because biodiversity protection does not fit within the traditional international transboundary pollution limitations on the exercise of sovereignty. The impairment of biodiversity will seldom constitute either transfrontier pollution or the degradation of a recognized global commons such as the oceans or regional airshed. In practice, nations have a sovereign right to exploit their territorial resources including land and biomass. ${ }^{60}$ Nonetheless, the international community is moving toward at least a weak or soft duty of biodiversity protection.

Since World War II, numerous global and regional conventions to protect endangered species and their habitats have been enacted, and procedures have been adopted to designate world heritage sites (such as the Grand Canyon National Park in Arizona and the Kakadu ecosystem in the Northern Territory of Australia). These efforts form the background ${ }^{61}$ of the 1992 United Nations

s8 The source of all local government authority is state delegation.

so See, for example, Claridge $v$ New Hampshire Wetlands Board, $125 \mathrm{NH} 745,485$ A2d 287, 291-92 (1984).

${ }^{\circ}$ Mohammed Bedjaoui, Some Unorthodox Reflections on the "Right to Development", in Francis Snyder and Peter Slinn, eds, International Law of Development: Comparative Perspectives 87, 94 (Professional Books, 1987), argues that the right "flows from the right to self-determination and is of the same kind." The emergence of this principle in the legal-political debates between the former Communist bloc and the developed countries is traced in George Elian, The Principle of Sovereignty Over.Natural Resources (Sijthoff \& Noordhoff, 1979).

${ }^{1}$ See Malcom J. Foster and Ralph U. Osterwald, Research Paper No. 25 (survey of 16 international legal instruments on nature conservation and terrestrial living resources) in Nicholas A. Robinson, ed, Volume 2, Agenda 21 \& The UNCED Proceedings 1099-171 (1992). 
Environmental Programme Convention on Biological Diversity ${ }^{62}$ which was not intitially signed by the United States, but now will be signed by President Clinton. ${ }^{63}$ The Convention affirms that "biological diversity is a common concern of humankind." Six requires that each nation "in accordance with its particular conditions and capabilities" shall "[d]evelop national strategies, plans or programmes for the conservation and sustainable use of biological diversity or adapt for this purpose existing" programs. ${ }^{65}$ The practical impact of this treaty on U.S. biodiversity protection law seems nil, even if we sign it. Nations may have a duty to conform their domestic legislation to international legal norms, ${ }^{68}$ but U.S. law already conforms to the general treaty standard. International law does not yet mandate local biodiversity protection, ${ }^{67}$ but it reinforces local power to act to this end. ${ }^{68}$

\section{B. Federal Law}

Federal law is not organized around the construct of biodiversity protection because the idea is so new. Federal public lands

\footnotetext{
62 See Stanley P. Johnson, ed, The Earth Summit: The United Nations Conference on Environment and Development (UNCED) 81-102 (Graham \& Trotman, 1993).

os Richard L. Berke, Clinton Declares New U.S. Policies for Environment, NY Times AI (Apr 22, 1993).

or Id at 82.

os Id at 85 .

66 "[T] to agreed international norms is usually regarded as implied under both conventional and customary international law ...." Jan Schneider, World Public Order of Environment (Toronto, 1979) excerpted as Jan Schneider, State Responsibility for Environmental Protection and Preservation, in Richard Falk, Friedrich Kratochwil and Saul H. Mendlovitz, International Law: A Contemporary Perspective 602, 607 (Westview, 1985).

${ }^{67}$ Commentators have argued that customary international law makes nation states the trustees of biodiversity reserves of international significance, such as those listed as world heritage sites under the Convention Concerning the Protection of the World Cultural and Natural Heritage, 27 UST 37, TIAS No 8226 (1972). See Lee P. Breckenridge, Protection of Biological and Cultural Diversity: Emerging Recognition of Local Community Rights in Ecosystems Under International Environmental Law, 59 Tenn L Rev 735, 741-44 (1992). The limits of customary environmental law have been harshly criticized because of the divergent interests of sovereign nations and the lack of an effective international adjudication process. Developments in the Law-International Environmental Law, 104 Harv L Rev 1484, 1498-520 (1991). This criticism somewhat underestimates the power of individual states to internalize emerging international norms. For example, the Australian High Court has held that the Commonwealth can implement the Treaty by legislation which supersedes power normally reserved to the federal states by the Australian constitution and tradition. See Commonwealth $v$ Tasmania, 46 Aus LR 625 (1983).

so "Litigants generally invoke international law only for illustrative purposes-to inform the statutory or constitutional commands that provide the real basis for action-rather than as a full-fledged source of law in its own right." Note, Judicial Enforcement of International Law Against the Federal and State Governments, 104 Harv L Rev 1269 (1991).
} 
management and environmental regulatory programs can be adapted to promote biodiversity, but there is no uniform federal approach to biodiversity protection. The two federal programs with the greatest potential to promote biodiversity are the management of the retained public lands such as national parks, monuments, and forests, and the Endangered Species Act ("ESA"). ${ }^{60}$ However, these programs fall short of the objective. Public lands management, including national park policy, is still commodityproduction driven, and the ESA remains under- and unevenly enforced. ${ }^{70}$

The ESA is the core federal biodiversity protection program. The ESA allows the Secretary of the Interior to list either threatened or endangered species ${ }^{71}$ and to designate the critical habitats of these species. ${ }^{72}$ Fish, wildlife, and plants may be protected under the ESA. ${ }^{73}$ Species must be listed solely on the basis of the best available scientific ${ }^{74}$ and commercial data, ${ }^{75}$ but the habitat designation standards permit a limited cost-benefit analy-

6916 USC $\$ \S 1531-1544$.

${ }^{70}$ Richard J. Tobin, The Expendable Future: U.S. Politics and the Protection of Biological Diversity 257-70 (Duke, 1990).

71 16 USC $\S 1533(\mathrm{a})(1)$. The distinction between threatened and endangered species introduces a margin of safety into the ESA. 16 USC $\$ 1532(20)$ defines a threatened species as one "which is likely to become an endangered species within the foreseeable future throughout all or a significant portion of its range."

Biologists define a species as an inbreeding population. Wilson, Biodiversity at 5-6 (cited in note 45). The ESA incorporates this concept and allows the Department of Interior to list threatened subspecies and distinct populations as well as the entire population. 16 USC § 1532(16). The decision of whether part of a population of a non-threatened species is endangered can raise some nice questions of advanced biology. See Note, The Concept of Species And The Endangered Species Act, 11 Va Envir L J 463, 485-86 (1992).

7216 USC \& 1533(a)(3)(A).

${ }^{73} 16$ USC $\S 1532(6)$.

74 Federal agencies have an affirmative duty to acquire the necessary information to make a scientifically informed decision. Roosevelt Campobello International Park Commission v EPA, 684 F2d 1041, 1052-53 (1st Cir 1982) (requiring real time simulation studies of effect of oil refinery on whales and eagles); Northern Spotted Owl v Lujan, 758 F Supp 621, 626 (W D Wash 1991) (Secretary of Interior has an affirmative duty to seek out biological and economic information necessary for determining critical habitat prior to final listing decision). However, the Secretary may proceed with an activity pending the acquisition of new information if no irremediable action is taken. Village of False Pass $v$ Watt, $565 \mathrm{~F}$ Supp 1123, 1155 (D Alaska 1983), aff'd as Village of False Pass $v$ Clark, 733 F2d 605 (9th Cir 1984). Occasionally, an agency can avoid this duty by showing that insufficient information is available to make a determination. Enos v Marsh, 769 F2d 1363, 1368-69 (9th Cir 1985).

75 16 USC \& $1533(\mathrm{~b})(1)(\mathrm{A})$. The consideration of commercial data is necessary to allow the United States to implement its duties under the Convention of International Trade in Endangered Species of Wild Fauna and Flora, 27 UST 1087, TIAS 8249 (1973), to which the United States is a signatory. 16 USC $\S 1531(\mathrm{a})(4)(\mathrm{F})$. 
sis. $^{78}$ The ESA imposes two primary protection duties. First, $\S 7$ prohibits all federal agencies from taking any action that jeopardizes the continued existence of any threatened or endangered species or results in the destruction or adverse modification of its habitat unless the agency has received a "God Squad" exemption. ${ }^{77}$ Section 7 protection duties are co-equal with an agency's other statutory mandates, which means that an agency cannot use its traditional discretion to "balance out" endangered species protection. ${ }^{78}$ Neither may judges balance the equities on review of agency action. ${ }^{79}$ Once an agency violates the Act, a court must enjoin the activity.

While $\S 7$ applies to local government activities that involve federal financing or that require a federal permit, $\S 9$ applies to all local activities that threaten to jeopardize a species or its habitat. ${ }^{80}$ Section 9 prohibits the "taking" of any listed fish or wildlife (but not plants) unless a permit has been obtained from the Secretary of the Interior. ${ }^{81}$ Section 9 applies both to hunting individual species and to "incidental" habitat destruction or modification which threatens a listed population. ${ }^{22}$ The Department of Interior initially tried to limit the definition of "takings" to habitat-modifica-

\footnotetext{
${ }^{76}$ The Secretary may exclude an area of a species' critical habitat if the benefits of the exclusion outweigh the costs, unless the exclusion of an area will result in the species' extinction. 16 USC § 1533(b)(2).

${ }^{27} 16$ USC \& 1536(a)(2), (h)(1).

78 Seattle Audubon Society v Evans, 952 F2d 297, 301-22 (9th Cir 1991) (US Forest Service subject to both National Forest Management Act and ESA).

79 Tennessee Valley Authority v Hill, 437 US 153, 173, 193-95 (1978). However, an injunction can only direct the agency to follow the statutory protection processes. Sierra Club v Yeutter, 926 F2d 429, 440 (5th Cir 1991).

so 16 USC \& 1538.

s1 16 USC $\$ 1538(1)(B), 1539$. The best treatment of $\S 9$ is Federico Cheever, An Introduction to the Prohibition Against Takings in Section 9 of the Endangered Species Act of 1973: Learning to Live With a Powerful Species Preservation Law, 62 U Colo L Rev 109 (1991). State endangered species protection laws may be broader. For example, plants are included in California's taking prohibition. Cal Fish \& Game Code $\S 2080$ (West Supp 1993). Department of Fish \& Game v Anderson-Cottonwood Irrigation District, 8 Cal App 4th 1554, 11 Cal Rptr 2d 222 (1992).

82 City of Las Vegas v Lujan, 891 F2d 927, 929 (DC Cir 1989) ("This restriction is of particular relevance to appellants, who allege that the listing at issue here will bring construction activity in southern Nevada to a standstill."); United States v Glenn-Colusa Irrigation District, 788 F Supp 1126, 1133-34 (E D Cal 1992) (district's withdrawals of water from Sacramento River were the proximate cause of death of listed winter run salmon); Department of Fish \& Game $v$ Anderson-Cottonwood Irrigation District, 8 Cal App 4th 1554, 11 Cal Rptr 2d 222, 231 (1992) (holding California Endangered Species Act prohibits irrigation withdrawals without proper fish screens because taking not limited to hunting or fishing); and Sierra Club v Lyng, 694 F Supp 1260 (E D Tex 1988), vacated as Sierra Club v Yeutter, 926 F2d 429 (1991) (destruction of Red-cockaded woodpecker habitat by clear cutting national forest violates taking prohibition).
} 
tion activities that actually kill or injure individual species, but the courts have defined a "taking" to include any habitat modifications that put a species at risk. ${ }^{83}$ Further, once the federal government demonstrates that a taking is likely to occur, it need only show that its proposed prohibitions will in fact prevent the taking. The government need not show that "the prohibition will itself operate to restore the species to a level considered unendangered." current regulation defines a taking as "an act which actually kills or injures wildlife. Such an act may include significant habitat modification or degradation where it actually kills or injures wildlife by significantly impairing essential behavioral patterns ...." 88 The equation of a taking with habitat destruction is consistent with both the general purpose of the $\mathrm{ESA}^{88}$ and with the legislative history of the original 1973 Act and the 1982 amendments. ${ }^{87}$ Municipal approval of development in a critical habitat was originally not a $\S 9$ taking because cities were not considered persons under the ESA, ${ }^{\mathbf{8 8}}$ but Congress amended the statute in 1988 to include "municipalities."

Habitat conservation on private property may also be required by the ESA, even though the powers of the Department of the Interior over non-federal land have traditionally been limited to actions necessary to protect adjacent public land management units. $^{90}$ Litigation filed by the Sierra Club to protect several threatened fish and reptiles supported by surface discharges from the overdrawn Edwards Underground Aquifer ${ }^{91}$ illustrates the potential reach of the ESA. ${ }^{92}$ Since the 1960 s, state and regional off-

${ }^{83}$ Palila $v$ Hawaii Dep't of Land \& Natural Resources, 649 F Supp 1070, 1075-76 (D Hawaii 1986), aff'd, 852 F2d 1106 (9th Cir 1988). See Robert D. Thornton, Searching for Consensus and Predictability: Habitat Conservation Planning Under the Endangered Species Act of 1973, 21 Envir L 605, 608-14 (1991) for a discussion of the role of the courts in shaping the current definition of $\S 9$ "takings."

state of Louisiana ex rel. Guste v Verity, 853 F2d 322, 333 (5th Cir 1988).

ss 50 CFR \& 17.3 (1991).

${ }^{86}$ See Palila $v$ Hawaii Dep't of Land \& Natural Resources, 471 F Supp 985, 995 (D Hawaii 1979), aff'd, 639 F2d 495 (9th Cir 1981); Palila v Hawaii Dep't of Land \& Natural Resources, 852 F2d 1106, 1108 (9th Cir 1988).

${ }^{87}$ See Sweet Home Chapter of Communities For a Great Oregon v Lujan, 806 F Supp 279, 285 (D DC 1992).

${ }^{83}$ United States v Rancho Palos Verdes, 841 F2d 329, 331 (9th Cir 1988).

8916 USC \& 1532(13) (1988).

90 Minnesota $v$ Block, 660 F2d 1240, 1249 (8th Cir 1981). ("As a necessary incident of [its Property Clause] power, [US Const, Art IV, $\S 3, \mathrm{cl} 2$ ] Congress must have the ability to insure these lands be protected against interference with their intended purposes.").

21 The acquifer is located between San Antonio and Austin, Texas.

${ }^{82}$ Sierra Club v Lujan, 1993 US Dist LEXIS 3361 (W D Tex 1991). 
cials studied and documented the need to allocate the aquifer, but the Texas courts, legislatures and administrative agencies consistently refused to limit withdrawals from the aquifer because the major users-farmers and the city of San Antonio-blocked proposed solutions.

In 1991, the Sierra Club, supported by a river authority, filed a suit alleging that the Secretary of the Interior had violated the ESA by failing to limit groundwater withdrawals that fed springs that supported the riverine habitats of several species listed or proposed for listing under the ESA. The nub of the suit claimed that federal officials had a duty to limit the use of state-created property rights by setting minimum critical aquifer levels for the state to maintain, in order to avoid liability under the ESA. Unlike surface water, Texas groundwater is the property of the overlying landowner and may be used for all legitimate purposes (subject to minor limitations). ${ }^{93}$ The suit prompted a novel state regulatory solution. The Texas Water Commission evaded Texas's Blackstonian groundwater law by declaring that the aquifer was an underground stream and thus subject to public regulation through the state's prior appropriation permit system. ${ }^{94}$ In February of 1993, a federal district judge ruled that withdrawals from the aquifer constituted takings of the fountain darter (one of the proposed listed species) and ordered the Texas Water Commission to "prepare a plan that, in its best professional judgment, assures that the Comal Springs and San Marcos Springs will not drop below jeopardy levels" set by the United States Fish and Wildlife Service. ${ }^{95}$

The fountain darter litigation illustrates the complex interrelationship among federal, state, and local biodiversity protection authorities. The federal government can effectively use federal courts to mandate state and local governments to take biodiversity protection measures. The threat of $\S 9$ liability will be a powerful incentive for state and local governments to implement protection measures. However, effective biodiversity requires fundamental changes in both state and local land use and natural resource laws

${ }^{23}$ See Friendswood Development Co. v Smith-Southwest Industries, Inc., 576 SW2d 21, 25 (Tex 1978).

o4 See 17 Tex Reg 6601-18 (1992); 31 Tex Admin Code § 297.1 (1992).

os Sierra Club v Lujan, 1993 US Dist LEXIS 3361 at *91. The Texas Water Commission is currently developing a multi-faceted plan to reduce aquifer withdrawals from the current 540,000 acre feet per year to $450,000-400,000$ acre feet per year in the face of projected increases in San Antonio's water needs. As the voice of western state water administrators notes, "[s]uch an undertaking would be unparalleled in Texas history." Western States Water, No. 992 (May 21, 1993). 
and policies. In the end, the limits of the remedial power of the federal courts and the realities of federal, state, and local politics create a need for mutual cooperation among all three levels of government. The next Section examines a necessary condition of local cooperation: adequate local authority to use delegated police powers to protect biodiversity.

\section{Local Authority To Protect Biodiversity}

Biodiversity protection is a logical extension of the exercise of the police power to promote the general welfare. Biodiversity protection combines the protection of sensitive areas with land use controls to supplement traditional sources of local revenue, such as property taxes, to finance public services. Biodiversity protection has not yet been explicitly identified as a legitimate police power objective, but courts have in fact endorsed it by sanctioning land use controls for a variety of purposes that we now describe as environmental. No doubt-courts will welcome biodiversity protection into the extended family of police power objectives by ratifying the social objectives articulated earlier in this Article. Biodiversity protection also draws from the expansion of the police power to encompass fiscal, aesthetic, ${ }^{96}$ and environmental regulation.

Cities will still face legal constraints in the formulation of biodiversity programs. Biodiversity protection will be challenged as a taking of private property, as ultra vires as a matter of state law, and as a preempted activity. More generally, biodiversity protection will be a troublesome issue for many judges because it takes the police power to the line between anthropocentric and non-anthropocentric theories of law. In both art and the law, the idea of nature rather than humans as an object of interest is an alien one. ${ }^{97}$ For sound reasons, courts have not recognized "rights" for animals, let alone natural systems, ${ }^{88}$ but they have accepted the idea that governments can err on the side of caution when sanc-

96 Doremus, 18 Ecol L $Q$ at 272 (cited in note 11) ("[G]enetic diversity is [a]esthetically valuable both because the differences among individuals may fascinate us (as in the case of our own species), and because it provides the building blocks from which new manifestations of nature's wonder can be constructed.").

${ }^{97}$ A recent essay by the dean of historians of 20th Century Western American art was written in part to refute Ralph Waldo Emerson's oft quoted quip that the "the trouble with the American West was that it was 'all out of doors.' " See Howard R. Lamar, Looking Backward, Looking Forward: Selected Themes in Western Art since 1900, in Discovered Lands Invented Pasts: Transforming Visions of the American West 167, 190 (Yale, 1992).

9s I have explored the reasons for this at greater length in A. Dan Tarlock, Earth and Other Ethics: The Institutional Issues, 56 Tenn L Rev 43 (1988). 
tioning intervention in natural systems, and are slowly coming to expand the definition of societal welfare to include the idea of healthy natural systems.98 The more recent state and lower federal court cases show an increasing understanding of many of the components of biodiversity protection. ${ }^{100}$

\section{A. General Welfare Zoning}

By the end of the 1960s, courts had rejected the common law of nuisance as a limitation on the exercise of police power and had endorsed the use of zoning to promote community welfare when the purpose of the regulation had no nuisance prevention purpose. Courts first upheld the use of zoning to enhance communities' fiscal stability through higher assessed values and lower service obligations. ${ }^{101}$ Land use controls to improve the appearance of a community were another important non-nuisance regulation upheld

90 Courts in Minnesota and Wisconsin have relied in part on Aldo Leopold's argument that "[a] thing is right when it tends to preserve the integrity, stability, and beauty of the biotic community. It is wrong when it tends otherwise," Aldo Leopold, A Sand County Almanac 224-25 (Oxford, 1968), to uphold legislation protecting wetlands and imposing landowner liability for inactive hazardous waste sites. See County of Freeborn v Bryson, 309 Minn 178, 243 NW2d 316, 322 (1976); In the Matter of Application of Christensen, 417 NW2d 607, 615 (Minn 1987); State v Mauthe, 123 Wis 2d 288, 366 NW2d 871, 878 (1985). For an analogous argument that local government linkage programs, which shift a portion of the costs of providing low and moderate income housing to developers, are a logical extension of the use of the police power to deal with the side-effects of rapid urban growth, see Jane E. Schukoske, Housing Linkage: Regulating Development Impact on Housing Cost, 76 Iowa L Rev 1011, 1039-47 (1991).

${ }^{100}$ See, for example, Puerto Rico Conservation Foundation v Larson, 797 F Supp 1066, 1072 (D PR 1992); Kern River Public Access Committee v City Bakersfield, 170 Cal App 3d 1205, 217 Cal Rptr 125, 141 (1985).

101 The use of zoning for fiscal objectives such as the maximization of the potential property tax base, arose when cities sought to enforce non-cumulative zoning ordinances. The early zoning ordinances had a hierarchy of uses, and higher uses could locate in lower zones as a matter of right. Non-cumulative zoning limits the uses in a district to those specified as permissible. This allowed cities to court light industry and office parks to pump up their tax base. A leading New Jersey case initially rejected non-cumulative zoning because it did not seek to prevent a nuisance, Katobimar Realty Co. $v$ Webster, 20 NJ 114, 118 A2d 824 (1955), but courts soon rejected this limit on the police power and endorsed the use of zoning to promote community fiscal welfare by encouraging high revenue generating-low service uses. See, for example, People ex rel Skokie Town House Builders v Village of Morton Grove, 16 III 2d 183, 157 NE2d 33, 36 (1959). Courts have also endorsed tying the pace of development to service capability. See, for example, Golden $v$ Town of Ramapo, 30 NY2d 359, 334 NYS2d 138, 285 NE2d 291, 304-08 (1972). However, fiscal zoning has its limits. The New Jersey Supreme Court has held that fiscal zoning is not a permissible use of the police power when it contributes to racial and economic exclusion. Southern Burlington County NAACP v Township of Mt. Laurel, 67 NJ 151, 336 A2d 713 (1975). Courts also prohibit zoning designed solely to lower the condemnation price of property. See, for example, Riggs $v$ Township of Long Beach, 109 NJ 601, 538 A2d 808 (1988). 
under this analysis. Aesthetic injury was not actionable at common law because the nature of the injury was subjective. Today, almost all states allow cities to regulate land use solely to achieve aesthetic objectives, although courts still assert the power to review both the reasonableness of the regulatory objective $e^{102}$ and the standards used to define the city's objective. ${ }^{103}$

\section{B. Flood Plain Zoning}

Zoning ordinances that prevent construction in one hundredyear flood plains are some of the earliest examples of zoning to preserve open space and promote environmental objectives. ${ }^{104}$ Floods were originally seen as natural disasters to be avoided by dams and levees. Gilbert White's pioneering work on flood control gradually convinced cities and the federal government that it would be more efficient to recognize that floods are positive natural processes and that humans should adapt to them by not putting costly permanent structures in flood plains. ${ }^{105}$ Flood plain zoning was initially puzzling to courts and commentators, because the fiscal benefits of land use controls were not well understood, and thus the protection of persons from their own folly seemed beyond the nuisance rationale. ${ }^{108}$ Flood plain zoning is now federal policy ${ }^{107}$ and has been uniformly endorsed by courts as a legitimate exercise of the police power. ${ }^{108}$ The standard justifications are the "protec-

\footnotetext{
${ }^{102}$ North Carolina was one of the last states to adopt the prevailing view. See State $v$ Jones, 305 NC 520, 290 SE2d 675 (1982).

${ }^{103}$ See, for example, Morristown Road Associates v Mayor \& Common Council, $163 \mathrm{NJ}$ Super 58, 394 A2d 157, 161-63 (1978).

${ }^{204}$ See Flood Control Act of 1936, § 1, Pub L No 74-738, 49 Stat 1570, codified at 33 USC $\S 701$ (a).

${ }^{105}$ The origins of the use of land controls in conjunction with and as a substitute for structural flood control measures are examined in Martin Reuss, Coping With Uncertainty: Social Scientists, Engineers, and Federal Water Resources Planning, 32 Natural Resources J 101, 117-23 (1992).

${ }^{108}$ See Allison Dunham, Flood Control via the Police Power, 107 U Pa L Rev 1098, 1107-17 (1959).

${ }^{107}$ The National Flood Insurance Act of 1968, Title XIII, Pub L No 90-448, 82 Stat 572 , codified at 42 USC $\$ \S 4001-4128$ (1988), requires cities to adopt flood plain zoning ordinances as a precondition to the availability of federal flood insurance. 42 USC § 4012(c). The Act was upheld in Texas Landowners Rights Association v Harris, 453 F Supp 1025 (D DC 1978), aff'd without opinion, 598 F2d 311 (1979). See Linda A. Malone, Environmental Regulation of Land Use § 7.02 (Clark Boardman, 1992) (detailed description of the federal insurance program).

${ }^{108}$ See, for example, McDougal v County of Imperial, 942 F2d 668, 675-80 (9th Cir 1991); Turner v County of Del Norte, 24 Cal App 3d 311, 101 Cal Rptr 93, 96 (1972); Vartelas v Water Resources Commission, 146 Conn 650, 153 A2d 822, 825 (1959); Beverly Bank v Illinois Department of Transportation, $144 \mathrm{IIl} 2 \mathrm{~d}$ 210, 579 NE2d 815, 821 (1991); Turnpike
} 
tion of individuals who might develop or occupy . . . land despite apparent danger to life or property; protection of others from damage caused by the obstruction of the natural flood flow; and protection of the community as a whole from the public expenditures otherwise necessary to safeguard property located within a flood plain."108

Flood plain zoning was not conceived of as a biodiversity protection program, but it can incidentally contribute to this objective. The ribbons of riparian vegetation along protected flood plains support large animal and plant populations. The Federal Emergency Management Agency has no authority to require the protection of these lands as a condition to federal flood insurance. Nevertheless, environmentally sensitive lands located in floodways are indirectly protected, since FEMA regulations prohibit encroachments which would increase flood levels. ${ }^{110}$ Some courts have even moved beyond the bounds of the early fiscal justifications, toward an ecosystem protection rationale. In upholding a flood plain zoning ordinance, a New Jersey court observed that the ordinance was a "proper exercise of the police power to prevent a misuse of nature . . .."111

\section{Open Space Preservation}

One of the most important shifts in post-World War II land use controls has been the emphasis on open space preservation in rapidly growing suburban and exurban areas. Open space preservation has now been conjoined with agricultural and conservation area protection. Large tract zoning in ongoing, predominately agricultural areas has been upheld as a legitimate use of the police

Realty Co. $v$ Town of Dedham, 362 Mass 221, 284 NE2d 891, 901 (1972); Responsible Citizens in Opposition to Flood Plain Ordinance $v$ City of Asheville, 308 NC 255, 302 SE2d 204, 209-10 (1983); Maple Leaf Investors, Inc. v State Dept of Ecology, 88 Wash 2d 726, 565 P2d 1162, 1164 (1977).

109 Turner $v$ Town of Walpole, 10 Mass App 515, 409 NE2d 807, 808 (1980). The argument that flood plain zoning violates the guarantee of equal protection of laws because it burdens flood plain landowners solely for the benefit of those outside of the hazard area has also been rejected. Responsible Citizens, 302 SE2d at 212-13.

$11044 \mathrm{CFR} \& 60.3(\mathrm{~d})(3)$ (1992).

"11 Usdin v State, 173 NJ Super 311, 414 A2d 280, 290 (1980), affd, 179 NJ Supr 113, 430 A2d 949 (1981). An important Montana case holds that a county may deny a subdivision (pursuant to statute) in an area where flooding has intensified as a result of prior development. Christianson v Gasuoda, 242 Mont 212, 789 P2d 1234, 1236 (1990). See also Mont Code Ann § 76-3-608(1) (1991). 
power under both fiscal and ecosystem protection rationales. ${ }^{112}$ Open space protection now includes programs that can evolve into biodiversity protection regimes.

Hawaii's statewide land use controls illustrate this potential. ${ }^{113}$ Hawaii's statewide zoning program enacted in 1961 included conservation zones. ${ }^{114}$ These districts, which include substantial portions of the major island counties, were designed primarily to protect watersheds. They consisted of state-owned forests and watersheds as well as private land placed in reserves in return for reduced property taxes. These districts have been managed under a multiple-use philosophy which allows many income uses compatible with biodiversity protection, ${ }^{115}$ but ongoing planning programs recommend the use of these zones to protect the Islands' rich legacy of native and rare biological resources. ${ }^{116}$

There is, however, a crucial difference between biodiversity protection as practiced in places such as California, Florida, and Texas, and traditional open space regulation that will pose problems for new protection regimes. Biological diversity preservation is science-driven, whereas much open space and related regulation reflects America's persistent anti-urban bias and a romantic nostalgia for the harmony of a lost arcadia. ${ }^{117}$ As a result, conven-

112 Barancik v County of Marin, 872 F2d 834, 835 (9th Cir 1988) (preserving agriculture); Boundary Drive Associates v Shrewsbury Township Board of Supervisors, $507 \mathrm{~Pa}$ 481, 491 A2d 86, 88 (1985) (same); City Nat'l Bank $v$ County of Kendall, 140 Ill App 3d 933, 489 NE2d 486, 488 (1986) (same).

113 Hawaii Rev Stat § 205 (1985 \& Supp 1992).

11 Act 187, 1961 Hawaii Sess Law 299.

115 Phyllis Myers, Zoning Hawaii: An Analysis of the Passage and Implementation of Hawaii's Land Classification Law 64-65 (Conservation Foundation, 1976). See David L. Callies, Regulating Paradise: Land Use Controls in Hawaii (Hawaii, 1984), for an analysis of the history of state land management. For an example of the application of multiple use, see Maha'ulepu v Land Use Commission, 71 Haw 332, 790 P2d 906, 909 (1990) (golf course reasonable use in agricultural district).

11 The 1992 draft State Land Use District Boundary Review: Oahu 59-68 (Hawaii Office of State Planning, March 1992) identified many habitats, mainly in lowland areas near the coast, which are not included in a Conservation District and recommends that most of these areas be reclassified as Conservation Districts.

${ }^{117}$ In his important exploration of the roots of modern ecology, Donald Worster traces the powerful influence of 18th century "arcadian ecology" on the 20th century thinkers whose ideas provide the foundation for modern environmentalism. Donald Worster, $\mathrm{Na}$ ture's Economy: The Roots of Ecology 1-25 (Sierra Club Books, 1977). For example, romantic views of nature have shaped our tendency to consider rural and urban areas two separate worlds instead of natural and social systems that are extensively integrated. See generally Cronon, Nature's Metropolis (cited in note 15). For a trenchant critique suggesting that this dichotomy promotes destructive environmental practices such as rapid urban sprawl, see Martin W. Lewis, Green Delusions: An Environmentalist Critique of Radical Environmentalism 87-101 (Duke, 1992). 
tional open space zoning will not always promote biodiversity protection because it is often equated with density controls. Density control zoning unconnected to a reserve program will not protect biodiversity. "Open space" ordinances often allow many inconsistent use categories such as paved trails, private yards, and landscaped areas to count in the calculation of open space. ${ }^{118}$

\section{Wetland Protection}

Wetland protection controls are an important biodiversity precedent, for they represent the most explicit, although controversial, recognition of the value of allowing ecosystems to perform their natural functions. The protection of wetlands will be an important component of any local biodiversity program, because the acknowledged environmental strategies can be adapted to protect other non-wetland resources. However, local governments have incomplete authority to control wetlands within their jurisdiction. ${ }^{119}$ The federal government has the primary regulatory authority over many wetlands under $\S 404$ of the Clean Water Act, ${ }^{120}$ and many state regulatory programs preempt or circumscribe local authority. ${ }^{121}$ Still, wetland protection is an important precedent for local biodiversity protection for two reasons. First, it is the most important use of the police power to protect a wide variety of natural system functions. Courts have sanctioned regulation to prevent pollution and to protect aquatic habitats, ${ }^{122}$ and Wisconsin has extended this precedent to uphold a lowland conservation zone which

118 For example, California requires detailed findings of fact to support a subdivision approval, Topanga Association for a Scenic Community $v$ County of Los Angeles, 11 Cal 3d 506, $113 \mathrm{Cal}$ Rptr 836, 522 P2d 12, 17-18 (1974), but this standard does not require findings on the quality of the open space offered by a developer to meet an ordinance requirement. Topanga Association for a Scenic Community $v$ County of Los Angeles, 214 Cal App 3d 1348, 263 Cal Rptr 214 (1989).

119 This is not necessarily bad. The leading example is Bersani $v$ Robichaud, 850 F2d 36 (2d $\mathrm{Cir} 1988$ ), which upheld the EPA's authority to veto a $\S 404$ permit issued by the U.S. Army Corps of Engineers when the EPA concluded that the developer should have chosen an alternative site for a regional shopping center. For a critical analysis of this decision see Fred P. Bosselman, Sweeden's Swamp: The Morass of Wetland Regulation, Land Use Law \& Zoning Digest 3 (Mar 1989).

${ }^{120} 33$ USC \$ 1344. See William L. Want, Law of Wetlands Regulation (Clark Boardman, 1989) for a complete discussion of the federal regulatory program. 107).

${ }^{121}$ See Malone, Environmental Regulation of Land Use at $\$ 4.10$ [1] (cited in note

122 See, for example, Crow-New Jersey 32 Limited Partnership v Township of Clinton, 718 F Supp 378, 384 (D NJ 1989) and cases cited therein; F.S. Plummer Co. v Town of Cape Elizabeth, 612 A2d 856, 860 (Me 1992); In the Matter of Application of Christenson, 417 NW2d 607, 615 (Minn 1987). 24 Vermont Stat Ann \& 4411(a)(2) (Equity Supp 1991) is a typical codification of the appreciation of wetland functions. 
encompassed a broader riparian corridor. ${ }^{123}$ Second, wetland protection has established the controversial idea that natural systems may be converted to more intense uses if the developer mitigates the habitat loss.

The power to regulate wetland filling includes the power to require mitigation. ${ }^{124}$ Mitigation allows a developer to replace lost habitat in return for permission to develop at a particular site. There are two views of mitigation. Under one view, mitigation is market environmentalism; the developer can choose to develop and pay for the losses either by providing an alternative habitat or by paying into a fund. The second view is that mitigation is a last resort, to be used when there is no way to avoid on-site wetland degradation. The second view is currently used in administering the $\S 404$ permit program. ${ }^{125}$ Wetlands mitigation has also produced the standard likely to be applied to biodiversity protection generally. In 1988, the broad-based National Wetlands Policy Forum recommended that the nation adopt the goal of "no overall net loss of the nation's remaining wetlands base, as defined by acreage and function . . ."128 The EPA has interpreted "no net loss" to require a one for one replacement of each acre filled. This standard can also be adapted to dry land habitat preservation. ${ }^{127}$

\section{E. Sensitive Lands Protection}

The environmental movement has promoted a more scientific approach to land use controls, and this has produced a variety of

${ }^{12 s} M$ \& I Marshall \& Ilsley Bank v Town of Somers, 141 Wis 2d 271, 414 NW2d 824, 831 (1987).

${ }_{124}$ Red Hill Coalition v Conservation Commission, 212 Conn 710, 563 A2d 1339, 1345 (1989). See also Mira Monte Homeowners Association v County of San Buenaventura, 165 Cal App 3d 357, 212 Cal Rptr 127 (1985) (discovery that street in subdivision would pave over wetland that supported five rare plants required supplemental environmental impact statement because orginal mitigation plan now in doubt). Mitigation requirements may be challenged as a taking or as a violation of substantive due process, but voluntarily agreed upon conditions may not subsequently be challenged on these grounds. Leroy Land Development v Tahoe Regional Planning Agency, 939 F2d 696 (9th Cir 1991) (dicta that off-site mitigation to protect Tahoe Basin ecosystem consistent with standards announced in Nollan v California Coastal Commission, 483 US 825 (1987)).

${ }^{128}$ Want, Law of Wetlands Regulation at $\$ 6.10[2][b]-[c]$ (cited in note 120).

${ }^{128}$ Final Report of the National Wetlands Policy Forum, Protecting America's Wetlands: An Action Agenda 3 (The Conservation Foundation, 1988).

${ }^{127}$ See Memorandum of Agreement between the EPA and the Department of the Army Concerning The Determination of Mitigation Under the Clean Water Act Section 404(b)(1), discussed in Want, Law of Wetlands Regulation at \$ 6.10[3] (cited in note 120). The use of this standard for farmland preservation is discussed in Anne E. Mudge, Protecting Farmland Through Impact Fees in California, Land Use Law \& Zoning Digest 3, 4 (Jan 1992). 
local "sensitive area" land use regulations on which biodiversity protection programs can also build. Environmental land use controls owe much of their genesis to Ian McHarg's 1971 book, Design With Nature, ${ }^{128}$ which was the first major work to apply principles of classic ecology to land use planning, and which continues to influence planners and lawyers. Design with Nature challenged the conventional wisdom that agricultural and undeveloped land should either be placed in "holding" categories until a specific development request was made, or preserved as public open space and recreational lands. Instead, Professor McHarg argued that sciences such as ecology and geomorphology should be used to delineate lands that are unsuitable for urban development because "certain types of lands are of such intrinsic value, or perform work for man best in a natural condition or, finally, contain such hazards to development that they should not be urbanized."129 His proposal was not a simple "develop or preserve" approach; he argued that a scientific carrying capacity analysis should be applied to determine the appropriate level of use and development. ${ }^{130}$ Carrying capacity analysis supported prior zoning such as flood plain zoning, and was extended to control development on a wide range of "sensitive" lands. ${ }^{131}$ Modern landscape ecology focuses on the effects of a landscape heterogeneity, geometry and the areal extent of ecological processes, and supports the more aggressive use of environmental land use controls and the greater use of environmental considerations. ${ }^{\mathbf{1 3 2}}$

Groundwater protection zoning is an important example of the use of zoning power to protect environmentally sensitive lands. ${ }^{133}$ The federal government has a comprehensive technology-based program to reduce surface water pollution, but groundwater protection and the control of non-point sources of pollution have been

${ }^{223}$ Ian L. McHarg, Design with Nature (Natural History Press, 1971).

129 Id at 154.

130 Id at 128.

131 See id at 57 .

${ }_{133}$ See, for example, Grant's Farm Associates, Inc. v Town of Kittery, 554 A2d 799 (Me 1989) (town could restrict 200 unit condominium, $90 \%$ of which would be open space, because of danger to nearby shoreline).

1ss The leading case is Moviematic Industries Corp. $v$ Board of County Commissioners of Metropolitan Dade County, 349 S2d 667 (Fla App 1977). See also Goddard v Board of Appeals of Concord, 13 Mass App 1001, 433 NE2d 98 (1982) (zoning power used to prevent construction in wetland area); Ketchel $v$ Bainbridge Township, 55 Ohio St 3d 239, 557 NE2d 779 (1990) (zoning power used to impose minimum lot size in groundwater area). 
left to state and local governments. ${ }^{134}$ There is a long tradition of watershed protection land use controls, but in the 1980s communities began to adopt sophisticated computer-based groundwater contamination ordinances. Communities that depend on vulnerable aquifers for their water supply have enacted ordinances to limit surface activities that threaten to contaminate the aquifer. ${ }^{135}$

Steep slope controls are another example of sensitive lands protection, and they illustrate the potential to limit land disturbance near protected habitats. Hillsides are prime building sites because of the values attached to vistas, but hillside development accelerates erosion and flooding. In the 1980 s, cities began to limit development on steep slopes. An early and somewhat incoherent Arizona opinion held that hillside zoning was a taking and expressed doubts about the ability of cities to use the police power to prevent steep slope development, ${ }^{136}$ but courts in Colorado ${ }^{137}$ and Pennsylvania ${ }^{138}$ have upheld these ordinances on rationales similar to the flood control zoning cases.

Resource protection zoning can evolve into biodiversity protection as communities and courts become more familiar with the concept. Judge Oakes's dicta in a Second Circuit opinion uphold-

136 See David H. Getches, Groundwater Quality Protection: Setting A National Goal for Federal and State Programs, 65 Chi Kent L Rev 387 (1989).

${ }^{135}$ Two of the most noted examples are Dade and Broward counties in Florida and Austin, Texas. The Florida counties have identified five concentric zones around their well fields based on the projected time that a contaminate would take to reach the groundwater. A given activity may be prohibited in the close zones and merely regulated in the more distant ones. Austin, Texas has sought to protect the recharge capacity of the Edwards Aquifer by designating critical water quality zones for different watersheds. For the Barton Creek watershed, which supports Barton Springs, the center of summer social life in Austin before the widespread availability of air conditioning, the ordinance designates buffer zones and uplands zones. Development in the first zone, which is basically the 100-year flood plain, is prohibited, low development densities are established in the second on a watershed basis, and relatively higher densities are allowed in the uplands. In another watershed, best management practices have been established for development to control run-off in lieu of density controls. Martin Jaffe and Frank DiNovo, Local Groundwater Protection 145-53 (American Planning Association, 1987). Austin's exercise of extra-territorial jurisdiction to control urban run-off was upheld in City of Austin v Jamail, 662 SW2d 779 (Tex App 1983). In 1992, by a two-to-one margin, Austin voters approved a referendum which decreased the permissible impervious cover percentage from $70 \%$ to $15 \%$ in order to protect Barton Springs, a 1,000-foot swimming hole in the center of the city, and its 354 square mile watershed. Austin votes 2 to 1 to save its spring, 9 US Water News 1 (Sep 1992).

138 Corrigan v City of Scottsdale, 149 Ariz 553, 720 P2d 528 (Ariz App 1985), aff'd in part, and vacated in part, en banc, 149 Ariz 538, 720 P2d 513 (1986). See also Beacon Hill Farm Associates II Limited Partnership v Loudon County Board of Supervisors, 875 F2d 1081 (4th Cir 1989).

${ }^{187}$ Sellon v City of Manitou Springs, 745 P2d 229, 232-33 (Colo 1987).

${ }^{138}$ Jones $v$ Zoning Hearing Board of McCandless, $134 \mathrm{~Pa} 435,578$ A2d 1369 (1990). 
ing a state's power to deny a development permit to preserve the habitat of a non-threatened species indicates how courts will resolve the vires issues. Vermont denied a subdivision approval under its statewide land use law because the proposed design encroached on a local deeryard. The Vermont statute allows the state to deny a permit if the development, inter alia, "will destroy or significantly imperil necessary wildlife habitat or any endangered species." ${ }^{138}$ Two members of the panel agreed only that the developer's takings claim was not ripe, but Judge Oakes proceeded to the merits concluding that the preservation of wildlife and their habitat "represents a legitimate state interest". ${ }^{140}$ Rejecting the developer's argument that because the whitetail deer were not threatened or endangered the state could not protect them, Judge Oakes went a step further, including a margin of safety: "[i]t is my view that the white-tailed deer population in Vermont need not deteriorate to such a level before protection of their winter habitat-especially in an area where little such habitat remains - can be said to 'substantially advance' Vermont's interest in preserving a healthy and populous deer herd."141

\section{Judicial, Constitutional, and Statutory Constraints}

A. Scientific Uncertainty, Judicial Review and Vested Rights

Courts are unlikely to impose per se prohibitions against biodiversity protection, but they will adapt existing doctrines of judicial review and control to monitor arbitrary exercises of the police power. Biodiversity protection initiatives may trigger this review because of the novelty of biodiversity protection. While land use controls are primarily negative-they inform landowners what they cannot do with their land-biodiversity protection is both negative and affirmative. Protection strategies do not simply prohibit inconsistent land use activities, they impose affirmative and often contingent obligations on landowners. For example, landowners must do species surveys and maintain long term monitoring programs. In the past thirty years, modern land use controls have increasingly imposed a list of performance obligations on a landowner in return for municipal permission to build. The long legacy of judicial distrust of local government endures, and the more that a land

$13910 \mathrm{Vt}$ Stat Ann § 6086(a)(8)(A) (Equity 1984).

${ }^{140}$ Southview Associates, Ltd. v Bongartz, 980 F2d 84, 109 (2d Cir 1992), cert denied, 113 S Ct 1586 (1993).

141 Id. 
use objective departs from the model of negative controls and imposes long term management obligations, the more courts will be sensitive to questions of fairness to the regulated landowners.

The legal burden on landowners will still be heavy, but the cities have a significant burden as well. Once the city establishes a rational nexus between the regulation and a legitimate environmental objective, the burden is on the landowner to demonstrate the scientific irrationality of the regulation. ${ }^{142}$ However, biodiversity protection does increase the burden of cities that approve developments in critical habitats, for a city must make detailed findings of fact to support its establishment of minimum necessary habitats. ${ }^{143}$

Two aspects of biodiversity protection will generate vagueness and vested rights challenges. Conservation biology is in the process of adapting hypothetic-deductive science to the demands of public regulation. Courts will be faced with two levels of uncertainty. The courts' familiarity with environmental regulations based on probabilities of risk has familiarized them with the problems of decisionmaking involving scientific uncertainty. Biodiversity protection involves this same problem of uncertainty, but also adds one of long term contingency. Conservation plans are ongoing scientific experiments subject to constant modification. Thus, there is (or should be) a constant interaction between new data and the plan. Habitat boundaries may be adjusted or management techniques modified to allow development options of varying intensity.

The inclusion of ordinance standards drawn from carrying capacity analysis and conservation biology may be challenged as unconstitutionally vague, but well-drafted ordinances will be upheld. A recent Maine Supreme Court case evinces increasing judicial sophistication in environmental regulation. A twenty-four acre waterfront parcel was zoned for resource protection; timber harvesting was allowed, provided well-distributed stands of trees remained and there were no openings in the forest canopy greater than 7,500 square feet. The owner clear-cut the stand, causing erosion and silt in local mussel beds, and the town sued to force the owner to restore the area. The property owner's primary defense was that the standard-"well-distributed stand"-was unconstitutionally vague,

${ }_{142}$ See, for example, Johnson v Sunray Services, Inc., 306 Ark 497, 816 SW2d 582, 58788 (1991).

14s Save the Pine Bush, Inc. v Planning Board, 130 AD2d 1, 518 NYS2d 466, 468 (1987) (city's failure to determine minimum habitat for endangered species before approving maximum permissible development was arbitrary and capricious). 
but the court found this argument disingenuous and held the standard consistent with modern resource conservation practices. The ordinance was not unduly vague because the requirement that a stand and canopy be left intact is a clear warning not to clearcut. $^{144}$ Similarly, a New York appeals court summarily rejected a vagueness challenge to a town's designation of shoreline areas as "coastal erosion hazard areas."145

As more and more communities and developers enter into long-term species conservation agreements, there will be considerable tension between the practice of adaptive management and legitimate demands for certainty by those undertaking or financing conservation management. In general, landowners will not be protected by the imposition of new conditions by either the law of vested rights or the language currently used in many agreements. The law of vested rights offers considerable protection to a single project, but much less to ongoing, phased developments-the very type of real estate development put at risk by biodiversity protection. ${ }^{146}$ The law of estoppel is even less favorable to developers. For instance, a local government is not estopped from exercising its police power until relatively late in the process. ${ }^{147}$ And, even if a local government is estopped as to one phase of a development, it is usually not estopped as to subsequent phases. ${ }^{148}$ Conservation

14 Town of Freeport v Brickyard Cove Associates, 594 A2d 556 (Me 1991).

${ }^{145}$ Dune Road Association of Westhampton v Jorling, 158 AD2d 448, 551 NYS2d 45, 46 (1990).

${ }^{248}$ Avco Community Developers, Inc. $v$ South Coast Regional Commission, 17 Cal 3d 785, 132 Cal Rptr 386, 553 P2d 546, 554-56 (1976) (property owner who had begun construction but did not have a building permit did not have vested right, nor was Commission estopped on the basis of sale of land to owner).

${ }_{147}$ F.B.R. Investors v County of Charleston, 303 SC 524, 402 SE2d 189, 190-91 (App 1991) (developer had not acted in reliance on county with respect to second half of land development despite completed construction in first half). But see Town of Largo $v$ Imperial Homes Corp., 309 S2d 571 (Fla App 1975) (town estopped due to developer's expenditures and good faith reliance). A local government can not be estopped from the future exercise of the police power after which an estoppel can, in theory, still be defeated by "public interest" considerations. Avco, $553 \mathrm{P} 2 \mathrm{~d}$ at 556 . This doctrine has been tempered by decisions upholding specific agreements between cities and developers and by statutes which allow cities and developers to enter into agreements which freeze regulations in place at the time of the contract. See, for example, Cal Govt Code $\$ 65865$ (a) (West Supp 1993) and Fla Stat Ann §§ 163.3220-3243 (West 1990). See generally Judith Welch Wegner, Moving Toward the Bargaining Table: Contract Zoning, Developer Agreements, and the Theoretical Foundations of Government Land Use Deals, 65 NC L Rev 957 (1987).

${ }^{148}$ See, for example, Rogin v Bensalem Township, 616 F2d 680, 682, 689 (3d Cir 1980). 
plans reflect this doctrine by tempering specific regulatory exemptions with an exception for changed conditions. ${ }^{149}$

Landowners who wish to challenge biodiversity measures will not be satisfied with the protection afforded by vires and vested rights for the reasons discussed in this Part. These landowners will use federal and state takings doctrine to try to block biodiversity protection programs. The next Part evaluates the likelihood of the success of these challenges under the Court's current takings jurisprudence and argues that the threat of government over-reaching is a legitimate concern, but also criticizes the Court's current direction because it is insufficiently sensitive to the idea of property as an ecological resource.

\section{B. Takings}

1. The jurisprudential puzzle.

Biodiversity protection programs will be challenged under the Takings Clause. The purchase or condemnation of property for biodiversity is a public purpose for which public funds may be used, ${ }^{160}$ but biodiversity protection raises serious regulatory takings issues. Restrictions may be severe, and will be site-specific, such that dedications of land for reserves and zoning ordinances limiting the amount of land that can be developed will be challenged as either temporary ${ }^{151}$ or permanent takings of private property without just compensation.

The line between a valid police regulation and a taking is one of the toughest contemporary jurisprudential puzzles. Neither the philosophical antecedents of the Constitution nor the intent of the framers provides sufficient guidance for a coherent takings jurisprudence. Taking "originally referred to the seizure of lands by the

140 See, for example, Metropolitan Bakersfield Habitat Conservation Plan (1991), discussed in Robert D. Thornton, Searching for Consensus and Predictability: Habitat Conservation Planning Under the Endangered Species Act of 1973, 21 Envir L 605, 632 (1991).

${ }^{180}$ There are few judicial controls on the exercise of eminent domain to acquire private property for a public objective, see Hawaii Housing Authority v Midkiff, 467 US 229 (1984) (redistribution of land ownership); City of Oakland v Oakland Raiders, 31 Cal 3d 656, 183 Cal Rptr 673, 646 P2d 835, 838 (1982) (football franchise); Poletown Neighborhood Council $v$ Detroit, 410 Mich 616, 304 NW2d 455 (1981)(automobile manufacturing plant), and the acquisition of biodiversity reserves will not in itself test the limits of government power to spend public funds to promote a valid police power objective.

${ }^{101}$ First English Evangelical Lutheran Church of Glendale v Los Angeles County, 482 US 304, 314-22 (1987). On remand, the California Court of Appeals found no temporary taking. 210 Cal App 3d 1353, 258 Cal Rptr 893 (1989). 
government,"152 but the modern notion that property can also be taken by regulation is a late twentieth century concept with few roots in history or Supreme Court jurisprudence. ${ }^{153}$ Though Professor Richard Epstein has tried to circumvent history by constructing a Lockean theory of private property immune from all regulation except that designed to prevent common law nuisances, ${ }^{154}$ the historical record reveals that the line between private and public was more fluid than modern property rights advocates acknowledge. ${ }^{155}$ The founders' understanding of property was similarly more complex, open-ended, and tolerant of government control. ${ }^{158}$ The net result is that the takings doctrine is best explained as one of the cluster of modern constitutional doctrines designed to protect relatively powerless minorities from the abuse of majoritarian power. ${ }^{167}$ The Supreme Court currently bases its jurisprudence on "our constitutional culture" rather than the framers' intent. ${ }^{158}$

In a familiar planner's joke, God answers the question "When will the takings muddle be resolved?" with "Not in my lifetime." The takings debate is about the extent of judicial protection prop-

162 Fred Bosselman, David Callies, and John Banta, The Taking Issue 51 (Council on Environmental Quality, 1973). There is considerable debate about the extent of pre-Revolutionary compensation for the expropriation of land for public improvements. Compare Morton J. Horwitz, The Transformation of American Law, 1780-1860 31, 47-53 (Harvard, 1977), and Note, The Origins and Original Significance of the Just Compensation Clause of the Fifth Amendment, 94 Yale L J 694 (1985), with James W. Ely, Jr., "That due satisfaction may be made:" the Fifth Amendment and the Origins of the Compensation Principle, 36 Am J Legal Hist 1 (1992).

${ }^{153}$ Glynn S. Lunney, Jr., A Critical Reexamination of The Takings Jurisprudence, 90 Mich L Rev 1892 (1992) (traces the meaning of a taking as a deprivation of a common law right during the Lochner era and its metamorphosis into a limitation on the power of the government to effect land values under the New Deal and subsequent Courts).

184 Richard Epstein, Takings: Private Property and the Power of Eminent Domain (Harvard, 1985).

${ }^{185}$ The fullest recent articulation of seventeenth and eighteenth century theories of property is Thomas L. Pangle, The Spirit of Modern Republicanism: The Moral Vision of the American Founders and the Philosophy of Locke (Chicago, 1988). In brief, Pangle argues that Locke's theory of original acquisition as a customary natural right pre-dating the organization of the state drew on the injunction of Genesis 1:28 to "Be fruitful, and multiply, and replenish the Earth," and was in fact a highly instrumental theory in promoting development both in England and in the New World. Id at 141-47. Locke's own theory recognized inherent limitations on the right of acquisition and thus Locke points toward government regulation, not away. Id at 164-69.

${ }^{136}$ Forrest McDonald, Novus Ordo Secorum 13-36 (Kansas, 1985).

${ }_{187}$ See John Hart Ely, Democracy and Distrust: A Theory of Judicial Review 97-98 (Harvard, 1980). This argument is more fully developed in Lunney, 90 Mich L Rev at 193555 (cited in note 153).

${ }^{188}$ Lucas v South Carolina Coastal Council, 112 S Ct 2886, 2900 (1992). 
erty owners require from representative government. ${ }^{150}$ There is no consensus within the judiciary or the academic community on this issue. With respect to biodiversity, some argue that environmental regulation strengthens the case for judicial protection; ${ }^{160}$ others reach the opposite conclusion. ${ }^{161}$ At the heart of the debate are two competing conceptions of property, between which the Supreme Court has sensibly refused to choose, because the underlying political theory debate is unresolvable. The federalist-natural law theory argues that acquisition generates firm expectations of property rights and that judicial protection is necessary to counter the mischief that governments are prone to do. ${ }^{162}$ The republican-positivist view stresses the relationship between the individual and the civil community, and subjects all claims to a public interest limitation. ${ }^{163}$ Scholars decry the Court's self-confessed doctrinal incoherence, and have offered the Court a great deal of advice on how to develop a takings jurisprudence. ${ }^{164}$ However, my view is that, with the exception of the government purpose inquiry, federal appellate decisions reveal a more coherent approach than appears at first glance.

The principal problem for modern takings jurisprudence is to decide when government regulation that decreases the market value of a tract of land but disturbs neither a common law title nor

168 This issue is part of the larger debate on the appropriate level of judicial restraint on local government. See Symposium on Law and Economics of Local Government, $67 \mathrm{Chi}$ Kent L Rev 707 (1991).

${ }^{160}$ See, for example, James S. Burling, Property Rights, Endangered Species, Wetlands, and Other Critters-Is It Against Nature to Pay for a Taking?, 27 Land \& Water L Rev 309 (1992).

${ }^{161}$ Professor Joseph L. Sax is the leading exponent of this position. See Takings, Private Property and Public Rights, 81 Yale L J 149 (1971); The Constitution, Property Rights and the Future of Water Law, 61 U Colo L Rev 257 (1990); and The Constitutional Dimensions of Property: A Debate, 26 Loyola LA L Rev 23 (1992).

${ }^{182}$ See Carol M. Rose, Mahon Reconstructed: Why The Takings Issue Is Still A Muddle, 57 S Cal L Rev 561, 588-92 (1984). Professor Jennifer Nedelsky argues that the Madisonian tradition has been the dominant one in American constitutional thought. Jennifer Nedelsky, Private Property and the Limits of American Constitutionalism: The Madisonian Framework and its Legacy (Chicago, 1990). See also Stephen R. Munzer, A Theory of Property (Cambridge, 1990).

103 Jerry L. Anderson, Takings and Expectations: Toward A "Broader Vision" of Property Rights, 37 U Kan L Rev 529, 531-33 (1989).

164 Justice Brennan's statement that the "Court, quite simply, has been unable to develop any 'set formula'", Penn Central Transportation Co. $v$ City of New York City, 438 US 104, 124 (1978), to decide when a taking has occurred, remains uncontradicted. Andrea L. Peterson, The Takings Clause: In Search of Underlying Principles Part I-A Critique of Current Takings Clause Doctrine, 77 Cal L Rev 1301 (1989) exhaustively documents the truth of Justice Brennan's statement with a detailed analysis of the Court's various definitions of property and takings formulas. 
an incident of possession and ownership requires compensation. Commentators have followed Bentham ${ }^{165}$ and defined property as a settled expectation of undisturbed use and enjoyment, and then asked the question, when can the government legitimately claim that a regulation does not frustrate expectations? The late Professor Allison Dunham contributed the most influential answer by distinguishing between government activities designed to prevent a landowner from undertaking an activity that harms other landowners and those designed to force a landowner to benefit others. ${ }^{168}$ Much subsequent commentary is a variant on this theme. ${ }^{167}$

Unfortunately, the harm-benefit distinction is, as the Court and commentators have indicated, too indeterminate to decide whether a compensable taking has occurred. ${ }^{168}$ However, it is relevant to the central issue in takings cases: when have legitimate expectations been frustrated? To this end, Professor Michelman has framed the issue as whether the state has given prior notice that it has preempted the right to exploit the resource. ${ }^{169}$

Common law property rights carry with them the expectation of full, unrestricted enjoyment. But this Blackstonian expectation has been eroding over time. To the extent that a state, either through legislation or judicial decisions, has identified harms that may result from the unfettered use of property, the property owner's reasonable expectation of compensation diminishes. Professor Sax has even suggested that erosion of these expectations over a long period and the establishment of a "noncompensation norm in circumstances of social change reflect[ ] a decision to encourage adaptive behavior by rewarding individuals who most adroitly adjust in the face of change."170

Historically, the state negated private rights in a limited class of common property resources: navigable waters and airspace. ${ }^{171}$

\footnotetext{
${ }^{20 s}$ Jeremy Bentham, Principles of the Civil Code, in Charles Milner Atkinson, trans, Bentham's Theory of Legislation, 114, 145 (Oxford, 1914).

${ }^{100}$ Allison Dunham, A Legal and Economic Basis for City Planning, 58 Colum L Rev 650,664 (1958).

${ }^{107}$ Professor Sax recast the harm-benefit test as an arbitration-enterprise versus appropriation and then as a conflict resolution versus expropriation test. Joseph L. Sax, Takings and the Police Power, 74 Yale L J 36, 67 (1964); Private Property and Public Rights, 81 Yale L J 149, 172 (1971).

${ }^{108}$ Frank I. Michelman, Property, Utility, and Fairness: Comments on the Ethical Foundations of Just Compensation Law, 80 Harv L Rev 1165, 1196-1201 (1967).

${ }^{169}$ Id at 1240.

${ }^{270}$ Joseph L. Sax, Property Rights and the Economy of Nature: Understanding Lucas v. South Carolina Coastal Council, 45 Stan L Rev 1433, 1449 (1993).

171 United States $v$ Rands, 389 US 121 (1967) (navigable waters); United States v Causby, 328 US 256 (1946) (airspace).
} 
But, the state has a broader power to limit private uses by putting landowners on notice that not all expectations will be honored. Over time, rules that limit activities based on scientifically demonstrated harm to similarly situated land uses become fair notice.

2. The "jurisprudence."

The incoherence of takings jurisprudence is a function of the rapid evolution of the field and the indeterminate nature of the underlying political theory. The Court waited until 1922 to hold that regulations which did not disturb actual title could be a taking. ${ }^{172}$ The Court finally adopted a systematic approach in 1978, in Penn Central Transportation Co. $v$ New York City, ${ }^{173}$ although the Court subsequently announced additional tests. Penn Central upheld the designation of Grand Central terminal as a free standing landmark by the City of New York, but its rationale remains problematic. The city prohibited the construction of a skyscraper over the terminal, but gave Penn Central transferable development rights ("TDRs") to offset the lost revenues. The land use community expected the decision to endorse or reject TDRs, but in the end the Court upheld the regulation as a straight zoning ordinance. Justice Brennan identified three relevant factors: (1) the regulation's economic impact on the claimant, (2) the extent to which the regulation interferes with investment-backed expectations, and (3) the character of the government's action. ${ }^{1745}$

Two years later the Court held that a regulation is a taking if it does not substantially advance a legitimate state interest or denies an owner economically viable use of his land. ${ }^{175}$ The change from Penn Central, if any, is minor. ${ }^{178}$

Penn Central's result can be defended as a no-deprivation case, since the landowner conceded that it was still earning a reasonable return from the original terminal. ${ }^{177}$ The problem with the opinion is that much of the majority's reasoning strips "notice" of any meaningful limitations, laying the foundation for the Court's current willingness to impose severe limitations on environmental

172 Pennsylvania Coal Co. v Mahon, 260 US 393 (1922).

173438 US 104 (1978).

174 Id at 124

175 Agins v City of Tiburon, 447 US 255, 260 (1980).

176 The court subsequently suggested that Agins applies to per se challenges and Penn Central to as-applied challenges, Hodel $v$ Virginia Surface Mining \& Reclamation Association, Inc., 452 US 264 (1981), but there is no constitutional justification for this distinction. A taking is a taking.

177438 US at $129 \mathrm{n} 26$. 
regulation. For example, the protection of a free standing landmark is not generally thought of as a harm prevention regulation, yet Justice Brennan suggested that the ordinance could be upheld on those grounds. ${ }^{178} \mathrm{He}$ also made it possible for other courts to transform notice into a theory which, in its more extreme form, suggests that changing land use regulations are the norm and thus holding land in anticipation of development will never support an investment-backed expectation. ${ }^{178}$

After Penn Central, the Court was divided on the issue of whether damages could be recovered for takings and made little substantive law; instead, it used ripeness to rebuff challenges. ${ }^{180}$ In 1987, the Court broke the damages impasse, but only one case, Keystone Bituminous Coal Association $v$ DeBenedictis, ${ }^{181}$ dealt with the standards for a regulatory taking. Keystone upheld a land subsidence prevention act very similar to the one Justice Holmes found to be a regulatory taking in Pennsylvania Coal $v$ Mahon. ${ }^{182}$ Justice Stevens' 5 to 4 majority opinion offered two reasons for the decision, one of which has been eroded by the Court's latest decision, and the other of which is the fragile cornerstone of environmental and biodiversity protection land use regulation. ${ }^{183} \mathrm{He}$ dis-

178438 US at $134 \mathrm{n} 30$.

170 See Daniel R. Mandelker, Investment-Backed Expectations: Is There A Taking?, 31 Wash U J Urban \& Contemp L 3, 9 (1987). Compare with Herrington v County of Sonoma, 790 F Supp 909, 924 (N D Cal 1991), which reduced an initial temporary takings award of $\$ 2.5$ million to $\$ 52,123.50$ plus interest by calculating the probability of approval of the proposed subdivision plan.

${ }_{180}$ Williamson County Reg. Planning Commission v Hamilton Bank of Johnson City, 473 US 172 (1985); MacDonald, Sommer \& Frates v Yolo County, 477 US 340 (1986). See also Daniel R. Mandelker and Brian W. Blaesser, Applying the Ripeness Doctrine in Federal Land Use Litigation, 11 Zoning \& Planning L Rep 49 (July/August 1988). Lucas $v$ South Carolina Coastal Council, 112 S Ct 2886 (1992), discussed in text accompanying notes 193-216, seems to reject much of the Court's previous ripeness teaching. Ripeness is no longer a jurisdictional prerequisite; it is now one of the Court's "prudential" discretionary balancing tests. Id at 2890-92. But see Sierra Club v California Coastal Commission, 12 Cal App 4th 602, 618, 15 Cal Rptr 2d 779, 784, review denied, Apr 1, 1993, discussed in note 208.

181480 US 470 (1987).

${ }^{162} 260$ US 393, 412 (1922).

${ }^{103}$ In a footnote in Lucas, 112 S Ct 2894 n 7 (1992), Justice Scalia cast doubt on the Court's continued adherence to the parcel-as-a-whole test, observing that the definition of property interest may turn on "how the owner's reasonable expectations have been shaped by the State's law of property ..." The Court of Claims and the Federal Circuit Court of Appeals appear to focus on the size of the regulated parcel rather than the total original parcel. Loveladies Harbor, Inc. v United States, 15 Cl Ct 381, 391-93 (1988); Florida Rock Industries, Inc. $v$ United States, $21 \mathrm{Cl} \mathrm{Ct} \mathrm{161,} \mathrm{164,} 176$ (1990). State v Schindler, 604 S2d 565 (Fla App 1992), review denied, 613 S2d 8 (1992), illustrates the significance of this factor. Florida denied a wetland fill permit for 1.85 acres of a 3.5 acre tract, and the trial court held that the state had taken only those 1.85 acres for which the permit was denied. The 
tinguished the earlier act as one for the protection of private landowners from the current legislation as intended to protect the public interest in health, the environment, and the fiscal integrity of the area. ${ }^{184}$ This is a labored distinction at best. Because takings law is a counter-majoritarian doctrine, a valid purpose alone is not sufficient to uphold a police power regulation. The sounder basis was the majority's conclusion that no investment-backed expectation had been frustrated. Only two percent of the company's coal had to be left in place, and deprivation had to be measured against a "reasonable unit of the petitioner's coal mining operations."185

The inquiry into the character or purpose of the regulation is a vestige of the Court's reliance on substantive due process to invalidate government regulation. It stems from an era when the police power was narrowly defined in order to minimize government interference with the exercise of individual rights. ${ }^{188}$ It has ceased to be a meaningful limitation on government regulations except in abuse of process cases and the relatively rare cases where a local government imposes land use regulation to cloak another, usually constitutionally suspect, purpose. ${ }^{187}$ Continued inquiry into the purpose of the regulation in the context of takings challenges only serves to confuse the issues. ${ }^{188}$ Simply put, private property is a

appellate court reversed, holding that the trial court should have considered the economic impact on the entire 3.5 acres.

184 Keystone, $480 \mathrm{US}$ at 474.

18s Id at 496,499 . The majority refused to follow Pennsylvania law which subdivided coal rights into surface, mineral and support estates. Id at 500-02. See also Hugh G. Montgomery, The Development of the Right to Subjacent Support and the "Third Estate" in Pennsylvania, 25 Temple L Q 1 (1951).

${ }^{188}$ See Herbert Hovenkamp, The Political Economy of Substantive Due Process, 40 Stan L Rev 379 (1988).

${ }^{187}$ The Supreme Court's post-Lochner due process is simply an ineffective test to police the regulation of land use. In a classic early land use article, the late Don Hagman listed the types of misuse of zoning which merit judicial control. They include: (1) disguised racial zoning, (2) lack of internal consistency within a jurisdiction, and (3) spurious motives. Donald G. Hagman, reviewing Richard F. Babcock, The Zoning Game, 34 U Chi L Rev 469, 47578 (1967).

18 Michael J. Davis and Robert L. Glicksman, To the Promised Land: A Century of Wandering and a Final Homeland for the Due Process and Takings Clauses, 68 Or L Rev 393 (1989) (traces the rise, fall, and resurrection of substantive due process in takings cases). But see Andrea L. Peterson, The Takings Clause: In Search of Underlying Principles Part II-Takings As Intentional Deprivations of Property Without Moral Justification, $78 \mathrm{Cal}$ L Rev 53 (1990). Professor Peterson argues that courts should determine "whether the lawmakers reasonably believed that the people of their jurisdiction would consider [] conduct to be wrongful." Id at 86 . Since Professor Peterson declines to specify how moral judgments should be made and she waffles on whether Penn Central can be justified on her test, it is difficult to tell whether her thesis is another restatement of the Dunham-Sax harm- 
combination of custom, ${ }^{189}$ estoppel ${ }^{180}$ and positive law. Thus the government must justify interference on one of two grounds: (1) the extent of the interference is not fair in a modern society; ${ }^{101}$ or (2) the landowner had a limited expectation that a claim would be constitutionally recognized..$^{192}$

The most recent Supreme Court case, Lucas v South Carolina Coastal Council, ${ }^{193}$ is the closest that the Court has come to applying its takings jurisprudence to biodiversity protection; the opinion has triggered an intense debate about the degree to which the Court has narrowed the scope of permissible environmental regulation. ${ }^{184}$ South Carolina passed a stringent barrier island protection act $^{185}$ and Lucas, who had purchased two periodically flooded lots for $\$ 975,000$, challenged the application of the Act to his lots after he was denied a building permit. Relying on the legislation's statement of purpose, the South Carolina Supreme Court upheld the

benefit test. Id at 142-43. If the moral justification collapses the harm-benefit test, it strays too far from the counter-majoritarian function of the Fifth Amendment.

The distinction has taken on added relevance because of the Supreme Court's ripeness barriers to takings claims. The Ninth Circuit has held that substantive due process claims are not subject to ripeness. See, for example, Sinaloa Lake Owners Association $v$ City of Simi Valley, 882 F2d 1398, 1405 (9th Cir 1989). Note, The Applicability of Just Compensation Claims to Substantive Due Process, 100 Yale L J 2667, 2685-86 (1991) argues that this is consistent with the Constitution but not with the Court's ripeness cases.

${ }^{189}$ Hirtz $v$ State of Texas, 773 F Supp 6, 9 (S D Tex 1991), vacated on other grounds, 974 F2d 663 (1992).

${ }^{100}$ Ruckelshaus v Monsanto Co., 467 US 986, 1010-14 (1984) (protected property interest in non-disclosure of trade secret data when Federal Insecticide, Fungicide, and Rodenticide Act guaranteed confidentiality).

${ }^{291}$ William A. Fischel, Exploring The Kozinski Paradox: Why is More Efficient Regulation A Taking of Property?, 67 Chi Kent L Rev 865, 869 (1991).

192 Keystone, 480 US at 485.

193112 S Ct 2886 (1992).

194 Lucas came down at the height of the 1992 election campaign and both police power and property rights hawks responded with pre-planned spins of the opinion. The reasons for this intense "hype" are well explored in Richard J. Lazarus, Putting The Correct "Spin" on Lucas, 45 Stan L Rev 1411 (1993). Police power hawks limit the holding to "rare" total deprivation cases, see, for example, Daniel Mandelker, Takings '92: The Case of the Curious Case, Land Use Law \& Zoning Digest 3.4 (Sep 1992); Barry I. Pershkow and Robert F. Housman, In the Wake of Lucas v. South Carolina Coastal Council: A Critical Look at Six Questions Practitioners Should be Asking, 23 Envir L Rep 10008 (Jan 1993), and property rights hawks stress the extent to which the Court has increased the burden that governments must bear to sustain a regulation. See, for example, Michael M. Berger, Planning Staffs "Outed" by Lucas Opinion, Land Use Law \& Zoning Digest 7-9 (Sep 1992), and Barry M. Hartman, Lucas v South Carolina Coastal Council: The Takings Test Turns A Corner, 23 Envir L Rep 10003 (Jan 1993). For a more balanced initial spin, see David L. Callies, The Lucas Case: Regulatory Takings Past, Present, and Future, Land Use Law \& Zoning Digest 4 (Sep 1992).

${ }^{10 s}$ Beach Management Act, SC Code Ann \$§ 48-39-10 through 48-39-360 (Law Co-op 1987 \& Supp 1992). 
permit denials because the act was intended to prevent a serious public harm. ${ }^{186}$ The Supreme Court reversed 7 to 2 in a decision that introduced some coherence into the law but sent a mixed message for biodiversity protection.

Justice Scalia's majority opinion identified two categories in which a presumptive taking occurs, and limited the justifications that a government may use to deny compensation. Regulation outside these two categories is, in theory, reviewed under the Penn Central test. In order to minimize the risk that "private property is being pressed into some form of public service under the guise of mitigating serious public harm,"192 Justice Scalia restated the physical invasion test and interpreted prior cases as finding a taking when a regulation denies all economically productive use of land. ${ }^{198}$

However, not all per se deprivations are unconstitutional. Justice Scalia first rejected the Dunham harm-benefit test because it was indeterminate, ${ }^{189}$ but then resurrected it as a crucial determinant of whether the property owner was on notice that title was subject to a pre-existing limitation. To defend such a taking, the government "must identify background principles of nuisance and property law that prohibit the uses he now intends in the circumstances in which the property is presently found." 200 These background principles are to be found in the common law of the fifty states-not in state legislation. Lucas brings some needed coherence to takings law by identifying notice as the key determinant of whether reasonable expectations have been frustrated by severe land use regulation, but the opaque "background" test introduces an unprecedented level of uncertainty and unevenness into the law. The test is intended to counteract the ability of governments

${ }^{198}$ Lucas v South Carolina Coastal Council, 304 SC 376, 404 SE2d 895, 896-98 (1991).

$19712 \mathrm{~S}$ Ct at 2895. This test was first articulated in Professor Joseph L. Sax, Takings and the Police Power, 74 Yale L J 36, 50 (1964).

$198112 \mathrm{~S} \mathrm{Ct}$ at 2895 . The test is phrased slightly differently in other opinions. Justice. Scalia's test is stricter than prior tests, see, for example, Agins v Tiburon, 447 US 255, 260 (1980)("economically viable use"), and it is unclear whether his formulation in Lucas differs in substance from this earlier standard. See, for example, $112 \mathrm{~S} \mathrm{Ct}$ at 2894 ("total deprivation of beneficial use"); id ("no productive or economically beneficial use of land is permitted").

$108112 \mathrm{~S} \mathrm{Ct}$ at $2897-99$.

$200112 \mathrm{~S} \mathrm{Ct}$ at 2901-02. The rejection of the harm-benefit test can be read as liberalizing the scope of police regulations, but Scalia's substitute-the background test-is clearly intended to limit the range of defenses to a taking by excluding modern environmental regulation. 
to justify regulations as nuisance-based, ${ }^{201}$ but it may expand the regulatory powers of states over waters and wetlands because these rights have always been defined in relation to other landowners and the public. ${ }^{202}$

The basic problem with Justice Scalia's approach is not in its theory, but in the narrow scope it gives to notice. It reflects an unjustified contempt for all levels of environmental regulation, no matter how clear the scientific link between a land use activity and harm to other land in the area, ${ }^{203}$ and a lack of appreciation for the extent to which the teachings of ecology have altered our conception of harmful land use practices. Justice Scalia views land as a commodity to be intensively developed and regards almost all government regulation, except traditional property stabilization zoning, ${ }^{204}$ as a forced redistribution of wealth. Environmental land use regulation is in fact designed to prevent long term harm to the sustainability of similarly situated parcels of larger ecosystems. ${ }^{20 s}$ Nothing in the common law prevents legislatures from expanding the concept of harm caused by certain types of land uses. ${ }^{208}$ There is a long tradition of sustaining the regulation of land use activities that injure the correlative rights of similarly-situated property

${ }^{202}$ See Comment, Is There a Doctrine in the House?: The Nuisance Exception to the Takings Clause Has Been Mortally Wounded By Lucas, 1992 Wis L Rev 1299, 1316. On remand, the South Carolina Supreme Court found no nuisance justification for the Beachfront Management Act, and remanded for a determination of temporary taking damages. Lucas v South Carolina Coastal Council, 424 SE2d 484, 486 (SC 1992).

${ }^{202}$ See, for example, Phillips Petroleum Co. v Mississippi, 484 US 469, 473-76 (1988), and Just v Marinette County, 56 Wis 2d 7, 201 NW2d 761, 768-69 (1972).

${ }^{203} \mathrm{See}$, for example, $112 \mathrm{~S} \mathrm{Ct}$ at 2889 ("South Carolina's expressed intent in intensively managing development activities in the 'so-called' coastal zone"). Scalia criticism has become a major cottage industry. My colleague Fred Bosselman has used this literature as the background for a measured evaluation of Justice Scalia's land-related opinions. He finds that Justice Scalia regards all land use regulation as inherently suspect, measures land by the human welfare it produces, believes that courts should promote the commodification of land, and treats legislative claims of scientific motivation with extreme skepticism. Fred B. Bosselman, Scalia on Land, in David L. Callies, ed, After Lucas: Land Use Regulation and the Taking of Property Without Compensation 82, 92 (ABA, 1993).

${ }^{204}$ City of Columbia v Omni Outdoor Advertising, Inc., 111 S Ct 1344, 1349-50 (1991).

${ }^{205}$ See Linda L. Butler, Private Land Use, Changing Public Values, and Notions of Relativity, 1992 BYU L Rev 629; David B. Hunter, An Ecological Perspective on Property: A Call for Judicial Protection of the Public's Interest in Environmentally Critical Resources, 12 Harv Envir L Rev 311 (1988).

${ }^{208}$ John A. Humbach, Evolving Thresholds of Nuisance and the Takings Clause, 18 Colum J Envir L 1, 23-26 (1993). But see The Supreme Court, 1991 Term, Leading Cases, 106 Harv L Rev 163, 274-76 (1992) (claiming that courts are superior to legislatures in identifying background conditions because they are less likely to overreach). 
owners. ${ }^{207}$ This tradition supports the state's power to define land use rights in terms of wider geographical impacts.

Regional ecosystem plans have the potential to avoid many takings problems because the larger geographic scale affords regulators more flexibility to permit compatible development. Many of the biodiversity protection schemes described in this Article involve large blocks of land, and may not prohibit all development, so it will be possible to craft strategies that meet the Lucas criteria, because the opinion suggests that it is limited to those relatively rare total deprivations of all conventional economic value. The opposite problem could, however, arise: Biodiversity mapping can identify impacted areas with greater precision, triggering immediate takings challenges. ${ }^{208}$

The necessary limits of notice are not easy to define, but the Supreme Court has never limited notice to land use activities proscribed by the common law of nuisance. ${ }^{209}$ Justice Kennedy's con-

${ }^{207}$ Ohio Oil Co. $v$ Indiana, 177 US 190, 203 (1900) (prevention of burning of natural gas to conserve common supply); Lindsley v Natural Carbonic Gas Co., 220 US 61, 75 (1911) (groundwater conservation).

${ }^{208}$ Lucas makes it easier to bring these challenges by making ripeness a prudential issue rather than a question of subject matter jurisdiction. See Thomas E. Roberts, Ripeness After Lucas, in David Callies, ed, After Lucas: Land Use Regulation and the Taking of Property Without Compensation 11 (American Bar Ass'n, 1993) Including a designation of land for public use in a comprehensive plan may be a taking if the government plans to acquire the property. Suess Builders Co. $v$ City of Beaverton, 294 Or 254, 656 P2d 306, 30812 (1982). On remand in this case, however, the plaintiffs did not convince a jury that this had happened, and the appellate court applied the state's law of ripeness to uphold the trial court's jury instruction. Suess Builders Co. $v$ City of Beaverton, 77 Or App 440, 714 P2d 229,233 (1986). Developers will analogize habitat conservation plans to official maps and invoke the line of cases holding that designation of land for future acquisition is an unconstitutional, "thinly veiled" effort to acquire land without paying just compensation. See, for example, Joint Ventures, Inc. $v$ Department of Transportation, 563 S2d 622, 625 (Fla 1990). However, a recent California intermediate court of appeals decision, Sierra Club $v$ California Coastal Commission, 12 Cal App 4th 602, 15 Cal Rptr 779 (1993), illustrates that the ripeness requirement may preclude many early challenges to biodiversity protection plans. Sierra Club was a public interest challenge to Mendocino County's refusal to designate the non-public lands portions of a unique coastal ecosystem, the pygmy forest, as environmentally sensitive habitat areas ("ESHA"). Mendocino County asked the state Coastal Commission to prepare the coastal element of a mandatory county land use plan, but did not implement the staff's suggestion that the non-public pygmy forest be protected from the adverse impact of development as ESHAs. Ultimately, the commission approved the county's alternative forest protection strategy, but a trial court set the approval aside because it was not supported by substantial evidence. The county defended the state approved plan as an early balance between takings and environmental protection considerations, but the Court of Appeals held that it was improper to consider takings issues before a specific landowner challenge was ripe for review. Id at 789.

${ }^{200}$ Hirtz $v$ State of Texas, 773 F Supp 6, 8 (S D Tex 1991), vacated on other grounds, 974 F2d 663 (1992), distinguished Nollan in holding that no taking occurred when Hurricane Alicia moved a beachfront lot seaward of the vegetation line and Texas subjected the 
curring opinion in Lucas rejected the common law of nuisance as limiting the state's power, observing that "[c]oastal property may present such unique concerns for a fragile land system that the State can go further in regulating its development and use than the common law of nuisance might otherwise permit."210 While the government cannot enact legislation for the purpose of denying just compensation, or deny compensation simply because it could exercise the police power to prevent the use, ${ }^{211}$ it may dampen expectations by putting property owners on notice that the enjoyment of their land will be regulated along with other similarly-situated landowners. Public land dedicated to a use that benefits adjoining land, such as a public park, may be lawfully changed to a more intensive use without violating the Fifth Amendment. ${ }^{212} \mathrm{~A}$ landowner may not claim compensation for a use that would have been unlikely to obtain regulatory approval because it would have harmed public resources. ${ }^{213}$ These principles were applied by the Indiana Supreme Court to uphold the denial of a variance to construct a building that would destroy a sand dune in the Indian Dunes National Lakeshore. ${ }^{214}$

The need for a strong takings doctrine to protect landowners from local government overreaching has often been exaggerated ${ }^{215}$ because of the wide variety of quasi-constitutional judicial controls over local land use controls. Local land use controls are technically either legislative or administrative functions. Courts initially treated local legislation with the same deference accorded federal and state legislation in post-Lochner jurisprudence. Zoning ordinances were presumed constitutional, and a minimum showing of

owner to a pre-existing public access easement. "While the owner's plight is serious, the acquisition of beach-front property carries with it the knowledge that the beach erodes and accretes over time." Id at 9.

$210112 \mathrm{~S} \mathrm{Ct}$ at 2903.

211 The best discussion of the limitations on the government's power to use its regulatory power to deny just compensation is Allison Dunham, Griggs v. Allegheny County in Perspective: Thirty Years of Supreme Court Expropriation Law, 1962 Supreme Court Review 63, 90-105.

212 Reichelderfer $v$ Quinn, 287 US 315, 323 (1932) (holding land owners have no appurtenant property rights to prevent the construction of fire station in adjacent park).

${ }^{213}$ United States $v 62.50$ Acres of Land, 953 F2d 886, 891 (5th Cir 1992) (land taken for Jean Lafitte National Historic Park properly valued as recreational rather than mining land because regulatory approval for mining "was a remote possibility" under state law).

${ }^{214}$ Town of Beverly Shores v Bagnall, 590 NE2d 1059, 1063-64 (Ind 1992).

216 Professor Callies has observed that the "erosion of private property rights by agencies of the federal government" is more troublesome than the risks posed by local governments. David L. Callies, Property Rights: Are There Any Left?, 20 Urban Law 597, 644 (1988). 
rationality was sufficient to justify the exercise of the police power. This formal analysis does not capture the modern judicial attitude toward local land use controls. State courts have intensified their review of local land use decisions. The reasons and standards are neither coherent nor uniform, but the net effect is to shift the presumption of validity in many cases. ${ }^{216}$

\section{Biodiversity Impact Fees}

Biodiversity protection schemes will require the acquisition of land as part of a habitat reserve design, although the land acquisition will vary depending on the specific ecosystem. Existing efforts use a combination of public and private funding sources-local governments rely on voluntary land dedications from developers or on the imposition of exactions such as "in lieu" and "impact" fees to finance the land acquisition. ${ }^{217}$ Functionally, impact fees are legislatively and judicially regulated taxes levied by rapidly growing local governments to supplement traditional sources of local tax revenue. Formally, courts and commentators maintain the fiction that impact fees are not taxes; thus the local government need not establish a specific delegation of the state's taxation power, because the fees are not intended to raise general revenues but to regulate an activity. ${ }^{218}$

Fictions have their uses, but the distinction masks the extent to which the line between general and special revenue raising devices has been blurred. Further, the fiction makes it difficult to un-

216 Professor Daniel R. Mandelker and I have explored this development at length in Daniel R. Mandelker and A. Dan Tarlock, Shifting the Presumption of Constitutionality in Land-Use Law, 24 Urban Law 1 (1992). We trace this shift to a general loss of faith in the progressive ideal of zoning, attributable to concerns about the racial and economic exclusion which results from classic low density suburban zoning and a general unease (often born of judges' first-hand experience with the process) with the abuses of land use controls.

212 "Exactions" is a general term which describes a number of methods used by local governments to shift the cost of accommodating new development directly to developers and housing purchasers. Technically, "in lieu fees" are fees in lieu of the dedication of land for specific facilities (for which mandatory dedications may be required under local subdivision law) and "impact fees" are fees levied on a proportional basis to fund large off-site public facilities to accommodate the pace of development in the community. See Brian W. Blaesser and Christine M. Kentopp, Impact Fees: The "Second Generation", 38 Wash U J Urban \& Contemp L 55, 63-68 (1990). There is a vast literature on subdivision exactions. See for example, Symposium, Exactions: A Controversial New Source for Municipal Funds, 50 L \& Contemp Probs 1 (1987); Theodore C. Taub, Exactions, Linkages, and Regulatory Takings: The Developer's Perspective, 20 Urban Law 515 (1988).

218 Occasionally, courts invalidate fees as taxes by determining whether the primary purpose is revenue raising or regulation. See, for example, Hillis Homes, Inc. $v$ Snohomish County, 97 Wash 2d 804, 650 P2d 193, 196 (1982). 
derstand why the courts created a hybrid revenue source but have circumscribed it so much more than formal taxes. ${ }^{219}$ Courts initially sanctioned impact fees to deal with immediate side effects of a new development, and legislatures authorized them for a wide variety of purposes. Both judicial decisions and legislation impose standards on their collection and use that are much more restrictive than those imposed on property and sales taxes. For example, there must be a demonstrated relationship between a new development and the public use made of the fees, ${ }^{220}$ the fees must not exceed any developer's proportionate fair share of the development, and the development must benefit from the public improvement. ${ }^{221}$

Mandatory dedications and fees have long been used to acquire land for parks and other open space uses, and the delegated authority to impose fees for this purpose should be sufficient to avoid vires challenges to biodiversity impact fees. ${ }^{222}$ Vermont authorizes municipalities to "accept offsite mitigation in lieu of an impact fee or as compensation for damage to important land such as prime agricultural land or important wildlife habitat."223 Biodiversity protection can be classified as open space or park acquisition, but potentially serious problems lurk in this analogy. Sciencedriven biodiversity protection programs, such as those discussed in Section IV, are premised on a demonstrated relationship between the dedication of land to habitat protection and protection of species viability. If this connection cannot be demonstrated, then the use of dedications and exactions becomes a distinctive open space program that could fail to meet the necessary linkage between the exaction and the mitigation of the problems caused by the devel-

210 Compare Nordlinger v Hahn, 112 S Ct 2326 (1992) (state may treat longtime homeowners differently from new purchasers), with Commercial Builders of Northern California $v$ City of Sacramento, 941 F2d 872 (9th Cir 1991).

220 Commercial Builders, 941 F2d at 875.

221 The rational nexus standard is the most widely followed. See Hollywood, Inc. $v$ Broward County, 431 S2d 606 (Fla App 1983). Blaesser and Kentopp, 38 Wash U J Urban \& Contemp $L$ at 86-94 (cited in note 217), discusses the evolution of this standard and compares it with other standards.

${ }^{222}$ J.W. Jones Companies v City of San Diego, 157 Cal App 3d 745, 203 Cal Rptr 580, (1984), is an especially interesting case. The court upheld a facilities benefit assessment on undeveloped land for park acquisition and rejected the argument that the parks must be contiguous to the assessed area. Id at 756. For an extensive collection of authorities, see James A. Kushner, Property And Mysticism: The Legality of Exactions as a Condition For Public Development Approval in the Time of the Rehnquist Court, $8 \mathrm{~J}$ Land Use \& Envir L 53, 98 n 250, 136 n 396 (1992).

22s 24 Vt Stat Ann $§ 5202(b)$ (Equity Supp 1991). 
opment. ${ }^{224}$ Many species, such as birds, may not conform to the theories of conservation biology.

Mandatory dedications, exactions, and impact fees have long been challenged as takings, and courts have generally rejected these challenges as long as a reasonable nexus existed between the development and the purpose of the fees. ${ }^{225} \mathrm{~A}$ reasonable nexus standard is analogous to the sliding scale equal protection standard proposed by Professor Gerald Gunther to replace the Court's twotiered equal protection review. ${ }^{226}$ Biodiversity protection is not unduly impaired under either standard. If credible science exists to justify the exercise of the police power, the exaction will be upheld under either minimum or rational nexus scrutiny. Heightened scrutiny would pose problems because the Court could question both the objectives and scientific basis for the regulation. Justice Scalia's majority opinion in Nollan v California Coastal Commis$\operatorname{sion}^{227}$ suggests that heightened scrutiny is constitutionally required, although state courts have not generally accepted his invitation.

Nollan illustrates that easy cases can make bad law. The facts are better suited for a Doonesbury cartoon than for Supreme Court litigation. Beach access has been a major resource issue in California for several decades because of limited public access to the usable portions of the Pacific coastline. A state land use agency, the California Coastal Commission, conditioned a building permit for Nollan's coastal lot between two public beaches on an easement across Nollan's dry sand area to connect the two parks. The principal rationale for the easement was that intense private shore line development prevented the public "psychologically" from realizing that public access exists in the vicinity. Nollan was an easy case for two reasons. First, the imposition of a common law servitude is a physical taking, and falls under the Court's per se rule. ${ }^{228}$ Second, the facts presented an appropriate occasion for the Court's occasional use of substantive due process to invalidate land use

\footnotetext{
${ }^{224}$ See Town of Longboat Key $v$ Lands End, Ltd., 433 S2d 574, 576 (Fla App 1983).

${ }^{225}$ See Nollan v California Coastal Commission, 483 US 825, 843 n 1 (1987) (Brennan dissenting) (collecting cases).

${ }^{228}$ Gerald Gunther, Foreword: In Search of Evolving Doctrine on a Changing Court: $A$ Model for a Newer Equal Protection, 86 Harv L Rev 1, 20-24 (1972).

${ }^{227} 483$ US 825 (1987).

${ }^{228}$ Lorretto v Teleprompter Manhattan CATV Corp., 458 US 419, 427 (1982).
} 
regulations that have a tenuous relationship to the accepted purposes of zoning. ${ }^{229}$

The Court, however, took a more novel and tortuous route to hold that the condition was unconstitutional. ${ }^{230}$ The real surprise was Justice Scalia's reasoning: he suggested that takings claims (as opposed to due process or equal protection claims) triggered a higher standard for determining whether the regulation advanced a legitimate state interest and whether there was an adequate nexus between the regulation and interest sought to be advanced. ${ }^{231}$ Yet state courts have consistently applied a two part test to determine whether a land use regulation is an invalid exercise of the police power. ${ }^{232}$

Justice Scalia's nexus test is straightforward, but it raises problems. It distorts state law despite his claim to the contrary, for the nexus test is more restrictive than the test most states apply. The majority's legitimate state interest and nexus test gives judges much more discretion to substitute their judgment for that of local bodies than state courts have thought necessary. This discretion is particularly troubling because Justice Scalia's property and land use jurisprudence reflects considerable skepticism with sciencebased regulatory programs.

Justice Scalia's purported reliance on background principles of state common law may be read as another invitation to ratchet up state nexus tests. To date, however, the impact of Nollan has been limited to similar factual situations. State courts have invalidated exactions which require access dedications unconnected to the development of the landowner's property, ${ }^{233}$ while most state courts have not accepted the Court's invitation to apply heightened scru-

\footnotetext{
220 See, for example, Moore $v$ City of East Cleveland, 431 US 494 (1977) (using substantive due process to invalidate ordinance which excluded a grandchild from living with his grandparents). See also Patrick Wiseman, When the End Justifies the Means: Understanding Takings Jurisprudence in a Legal System With Integrity, 63 St John's L Rev 433, 447-51 (1989).

2so Professor Frank Michelman, Takings, 1987, 88 Colum L Rev 1600, 1605-14 (1988), has effectively parsed and criticized the opinion.

231483 US at $834 \mathrm{n} 3$.

${ }^{232}$ A-S-P Associates $v$ City of Raleigh, 298 NC 207, 258 SE2d 444, 448-49 (1979) is a typical statement of the ends-means analysis: "First, is the object of the legislation within the scope of the police power? Second, considering all the surrounding circumstances and particular facts of the case is the means by which the governmental entity has chosen to regulate reasonable?" The second inquiry is a two-pronged analysis. "(1) Is the statute in its application reasonably necessary to promote the accomplishment of a public good and (2) is the interference with the owner's right to use his property as he deems appropriate reasonable in degree?" Id at 449.

23s Daniel R. Mandelker, Land Use Law § 9.17.50 (Michie, 2d ed, Supp 1992).
} 
tiny to exactions ${ }^{234}$ and environmental regulations. Environmental exactions have been upheld, ${ }^{235}$ and property owners still bear the burden of proving that the regulation denied all economically viable uses of the land. ${ }^{236}$

\section{Equal Protection}

Biodiversity protection requirements will almost inevitably raise equal protection challenges as well. To a land developer, all land capable of development is a similar commodity, ${ }^{237}$ but to a conservation biologist, similarly situated tracts of land may serve very different biodiversity maintenance functions. If the local government can defend the underlying science in court, differential treatment of similarly situated tracts should not be considered a denial of equal protection to the regulated landowner. However, many local governments will face the "last undeveloped corner" problem. ${ }^{238}$ That is, prior development will have destroyed a substantial amount of habitat. In the gas station cases, courts have often held that it is unfair to buck the market after most other property owners have been allowed to develop. ${ }^{239}$ However, the Vermont deeryard case has come to the opposite conclusion. It upheld the dismissal of an equal protection claim by the "last" subdivider because the threatened wildlife habitat was now unique to the area. ${ }^{240}$

Partial species listings also raise classic underinclusion issues, but the opponents of the listing will face a heavy equal protection burden in establishing that such a decision is scientifically irrational. In the emergency listing of the desert tortoise, the Secretary

${ }^{234}$ See, for example, Blue Jeans Equities West $v$ San Francisco, 3 Cal App 4th 164, 4 Cal Rptr 2d 114, 115 (1992) (heightened scrutiny does not apply to exactions).

${ }^{235}$ Gardner v New Jersey Pinelands Commission, 125 NJ 193, 593 A2d 251, 262 (1991).

${ }^{238}$ Gil v Inland Wetlands \& Watercourses Agency, 219 Conn 404, 593 A2d 1368 (1991); Carabell v Department of Natural Resources, 191 Mich App 610, 478 NW2d 675, 676 (1991).

${ }^{237}$ My colleague, Fred P. Bosselman, has explored the influence of this idea on Illinois land use law. The Commodification of "Nature's Metropolis": The Historical Context of Illinois' Unique Zoning Standards, 12 NIU L Rev 527 (1992).

${ }^{238}$ Courts have long implicitly used the equal protection standard to invalidate the refusal to "upzone" a tract after similarly situated parcels have been rezoned. See, for example, Jurgens $v$ Town of Huntington, 384 NYS2d 870 (1976). Lucas could have been decided on equal protection grounds, since the state simply acted too late to protect the strip in which the plaintiff's property was located. $112 \mathrm{~S} \mathrm{Ct}$ at 2889. 1975).

${ }^{238}$ See Norman Williams, 4 American Land Use Planning Law \$ 93.03 (Callaghan,

${ }^{240}$ Southview Associates, Ltd. and Southview at Stratton Partners v Bongartz, 980 F2d 84, 91, 103 (2d Cir 1992). 
of the Interior included the Mojave population in northwestern Arizona, California, Nevada and Utah but excluded the Sonoran population in southern Arizona because those tortoises were thought to be free of a respiratory disease which existed in the Mojave range and sufficiently buffered from the disease's spread to the south. In a challenge to the listing, the court did not rule on the merits of the exclusion but did observe "[s]ince agencies have great discretion to treat a problem partially, we would not strike down the listing if it were a first step toward a complete solution, even if we thought it 'should' have covered both . . p populations."241

\section{E. Preemption}

Local government biodiversity programs are in danger of being squeezed out through state and federal preemption. However, with the possible exception of wildlife law, current federal and state preemption does not constrain biodiversity protection. Local government regulation will be strengthened by Supreme Court and state court preemption decisions which have drawn a distinction between the prohibition and the supplemental regulation of an activity, although these generalizations fall in the face of more explicit state preemption or occupation of an area. ${ }^{242}$ These decisions sanction a wide variety of concurrent environmental regulation against implied preemption challenges. Their reasoning rests on the Supreme Court's respect for state sovereignty and the unarticulated assumption that concurrent environmental regulation often supplements rather than frustrates the objectives of a federal program. In a number of contexts, courts have assumed that regulatory programs designed to control external costs will underestimate these costs; the courts therefore presume state and local environmental regulations are complementary. ${ }^{243}$ The Supreme Court

${ }^{241}$ City of Las Vegas $v$ Lujan, 891 F2d 927, 935 (DC Cir 1989).

${ }^{342}$ The two standard preemption tests are legislative intent to preempt or to occupy a field. Courts have great latitude in applying these tests and, therefore, no consistent law of preemption has arisen within or among the states, despite the large number of land use preemption cases in state courts. Compare, for example, Board of County Commissioners $v$ Bowen/Edwards Associates, 830 P2d 1045 (Colo 1992) (state oil and gas conservation does not completely preempt local land use regulation), with Newbury Township v Lomak Petroleum (Ohio), Inc., $62 \mathrm{Oh} \mathrm{St} \mathrm{3d} \mathrm{387,583} \mathrm{NE} \mathrm{2d} 302$ (1992) (state well spacing laws preempt local regulation of oil well location).

${ }^{343}$ Crow-New Jersey 32 Limited Partnership v Township of Clinton, 718 F Supp 378, 385-88 (D NJ 1989). The modern "balancing test" to resolve interlocal conflicts is another example of the presumption that dual regulations are necessary to internalize the costs of an activity. Courts originally applied a hierarchical approach to resolve inter-governmental land use conflicts, but many modern cases adopt a balancing test. The leading cases include 
has upheld state power to require a permit to perfect a mining patent in a national forest ${ }^{244}$ and local controls on the use of federally registered pesticides. ${ }^{245}$ States have upheld local power to regulate extractive mining subject to state requirements on the same rationale. ${ }^{246}$

Wildlife is the major exception to the presumption of local control. Local governments must honor state wildlife decisions, unless the state decision is preempted. This will require them to either allow hunting authorized by state law or implement endangered species protection programs. States have the primary control over wildlife within their borders. As the successors to the Crown of England, ${ }^{247}$ they own wildlife within their borders to the exclusion of private owners, ${ }^{248}$ and they can therefore preempt local reg-

Rutgers $v$ Piluso, 60 NJ 142, 286 A2d 697 (1972), and City of Temple Terrace $v$ Hillsborough Association for Retarded Citizens, Inc., 322 S2d 571 (Fla App 1975), aff'd 332 \$2d 610 (1975). See Edward H. Ziegler Jr., Governmental Immunity From Zoning: Balancing of Interests and Legislative Intent, in Kenneth H. Young, ed, 1992 Zoning and Planning Law Handbook 109, 113-21 (Clark Boardman, 1992) for a survey of the recent cases.

244 California Coastal Commission v Granite Rock Co., 480 US 572, 581-93 (1987). The mining company argued that Congress has unlimited power over federal lands under the Property Clause, Kleppe v New Mexico, 426 US 529, 539 (1976), and Congress has delegated exclusive land use authority to the federal land management agencies. To reject this argument, the Court drew an artificial distinction between environmental regulation and land use planning which may pose problems for future state and local regulation. Granite Rock, 480 US at 587. See John D. Leshy, Granite Rock and the State's Influence Over Federal Land Use, 18 Envir L 99 (1987); Richard H. Cowart and Sally K. Fairfax, Public Lands Federalism: Judicial Theory and Administrative Reality, 15 Ecol L Q 375 (1988); Comment, A Consideration of Federal Preemption in the Context of State and Local Environmental Regulation, 9 UCLA J Envir L \& Policy 97 (1990).

245 Wisconsin Public Intervenor v Mortier, 111 S Ct 2476, 2487 (1991).

${ }^{246}$ Frew Run Gravel Products, Inc. v Town of Carroll, 71 NY2d 126, 524 NYS2d 25, 518 NE2d 920, 924 (1987). Compare Voss v Lundvall Brothers, Inc., 830 P2d 1061, 1068-69 (Colo 1992) (home rule cities may regulate but not preclude oil and gas drilling within their boundaries).

${ }^{247}$ Martin v Lessee of Waddell, 41 US 367 (1842). The Supreme Court originally justified state control on the theory of state ownership of things ferae naturae in trust for the people of the state. Geer $v$ Connecticut, 161 US 519, 523-29 (1896). Geer held that a state could prevent the export of its game across state lines, id at 535, but the Court has since held that state ownership does not immunize state game laws from the Dormant Commerce Clause. Hughes v Oklahoma, 441 US 322, 335 (1979). However, absent federal preemption, state control remains the norm even when it seeks to advance the interests of its citizens against those of other states. Baldwin $v$ Montana Fish and Game Commission, 436 US 371, 388 (1978). See generally Michael J. Bean, The Evolution of National Wildlife Law (Praeger, 2d ed, 1983); Thomas A. Lund, British Wildlife Law Before the American Revolution: Lessons from the Past, 74 Mich L Rev 49 (1975); Winston Harrington, Wildlife: Severe Decline and Partial Recovery, in Kenneth D. Frederick and Roger A. Sedjo, eds, America's Renewable Resources: Historical Trends and Current Challenges 205 (Resources for the Future, 1991).

${ }^{248}$ Betchart $v$ Department of Fish and Game, 158 Cal App 3d 1104, 205 Cal Rptr 135 (1984). This principle was applied in Mountain States Legal Foundation v Hodel, 799 F2d 
ulation. ${ }^{249}$ States have traditionally exercised their Tenth Amendment power over wildlife to regulate hunting and fishing and to conserve adequate sport populations. State power is subject to the federal government's ample constitutional power to protect wildlife under the Commerce and Property Clauses, ${ }^{250}$ but Congress has limited this power to threatened species.

Local governments are now devising biodiversity protection strategies which require them to thread their way through vires, takings law, preemption, and other limits on their regulatory authority. It is premature to evaluate the success of these efforts, which are in various stages of implementation, but the next Section surveys the major initial protection efforts, which are primarily in response to the Habitat Conservation Plan option provided by $\S 10$ of the Endangered Species Act.

\section{Local Biodiversity Protection Initiatives}

\section{A. First Generation HCPs}

The Habitat Conservation Plans ("HCPs") authorized under $\S 10$ of the Endangered Species Act are the current focus of local

1423 (10th Cir 1986), to deny a taking claim by the landowners who alleged that the Bureau of Land Management's failure to manage wild horses damaged the value of the landowners' private grazing leases and federal permits. See also Christy v Hodel, 857 F2d 1324 (9th Cir 1988) (protected grizzly bears did not take property of federal grazing permittee when they devoured some of his sheep). But see Fallini $v$ Hodel, 725 F Supp 1113 (D Nev 1989), aff'd on other grounds, 963 F2d 275 (1992) (wild horses who destroyed grazing permittee's well on public lands constituted a taking).

240 See Missouri v Holland, 252 US 416, 430-32 (1920). State wildlife primacy is so well established that the principle is seldom litigated. A recent Alaska Supreme Court opinion, State $v$ Kluti Kaah Native Village, 831 P2d 1270 (Alaska 1992), illustrates the breadth of state power against an unusually strong local interest. Indigenous Alaskans and state residents have a statutory right to subsistence hunting, Alaska Stat $\S 16.05 .258$ (1990), and the court has created a two-tiered system of subsistence hunts to maintain sustainable herds and fish stocks. See Madison v Alaska Dep't of Fish and Game, 696 P2d 168 (Alaska 1985). See also McDowell v State, 785 P2d 1 (Alaska 1989). In 1991, the Board of Game adopted a single seven-day moose hunt for all subsistence hunters designed to harvest 600 moose. Kluti Kaah, 831 P2d at 1271. A native village successfully obtained a preliminary injunction against the hunt on the grounds that it was too short to satisfy the village's winter subsistence needs, and too short to pass on the skills of subsistence hunting to young hunters. Id at 1272. The Supreme Court reversed because the trial court failed to give sufficient weight to the interests of the state.

2s0 In the face of Geer, 161 US 519, federal regulation of wildlife was initially justified by the Treaty power, Holland, 252 US at 432-35, but federal power now rests either on the Property Clause, Kleppe, 426 US at 535-41; Minnesota v Block, 660 F2d 1240, 1248-51 (8th Cir 1981), or the Commerce Clause, United States $v$ Helsley, 615 F2d 784, 786 (9th Cir 1979). See George Cameron Coggins and Robert L. Glicksman, Public Natural Resources Law § 18.02[4] (Clark Boardman, 1993). 
government involvement in biodiversity protection. First generation HCPs were adopted to devise quick fixes to the belated discovery of a listed species in the path of a large development. The discovery of an endangered population typically came toward the end of a local growth control battle, and introduced a powerful new constraint on development which put both developers and cities at risk if they failed to protect the species. ${ }^{251}$ Endangered species issues introduce unique constraints on land planning. Unlike other environmental programs, endangered species protection contains substantive-not just procedural-standards that change the outcomes of local land use plans and ordinances. The prior focus on preserving single species is slowly evolving into a more comprehensive approach to species protection, although the jury is still out on the ability of the process to achieve this objective.

HCPs were a direct congressional response to a series of classic 1970s environmental land use conflicts in northern and southern California. ${ }^{262}$ The discovery of two butterfly communities on San Bruno Mountain, immediately south of San Francisco, and a very tough lizard in the Coachella Valley, west of Palm Springs, led to the first HCPs. San Bruno Mountain was the last large open space capable of development on the Bay Side of the San Francisco Peninsula when a large development was proposed in 1975. By 1980, environmentalist opponents had succeeded in shrinking the initial proposal by three-quarters, and public entities had acquired 1,948 acres of state and local parkland. ${ }^{253}$ Two butterflies found almost exclusively on the mountain, one listed and the other proposed, threatened to bring even the scaled-down project to a standstill.

The developers initially tried to block the proposed listing and habitat designation of the callippe silverspot butterfly, but the listed mission blue butterfly induced the developers to cooperate with local governments, state and federal officials, and environmentalists to prepare a survey and develop a recovery plan for the two populations. Biologists identified the specific habitat needs; the developers agreed to impose servitudes to restrict use and to kick in an additional 800 acres, the costs of which were passed on

${ }^{251}$ See Sally Bond Mann, Uplands Regulation: Habitat for Man or Beast?, $7 \mathrm{~J}$ Land Use \& Envir L 59 (1991).

282 See Michael J. Bean, Sarah G. Fitzgerald and Michael A. O'Connell, Reconciling Conflicts Under the Endangered Species Act: The Habitat Conservation Planning Experience 7-10 (World Wildlife Fund, 1991).

${ }^{233}$ Bean, Reconciling Conflicts at 52 (cited in note 252). 
to housing purchasers ${ }^{254}$ (bringing the total preserved open space on the mountain to eighty percent), and agreed to a permanently funded plan to protect the habitat from construction activities.

This deal became the prototype for the $\S 10$ process, and in 1983 the Fish and Wildlife Service issued an incidental take permit for the mission blues, allowing development to go forward. Monitored by a local committee, the plan has survived challenges to its scientific basis, ${ }^{258}$ to the affordable housing opportunities that it foreclosed, ${ }^{258}$ and to amendments. ${ }^{257}$ Preliminary assessments of the plan measured by butterfly populations and developer compliance with grading restrictions are hopeful, although the monitoring and habitat restoration proposals in this area have been criticized. ${ }^{258}$

California's Coachella Valley in eastern Riverside County is a living testimony to our ability to manipulate nature and is the site of the first $\S 10$ HCP approval. A harsh low desert area had been turned into an agricultural and recreational oasis through irrigation. The efforts of a University of California at Riverside zoologist succeeded in listing the fringe-toed lizard as a threatened species. This controversial and contested listing interjected environmental issues into an area that had little experience with any form of growth limitations. The possibility of myriad threatened desert species from Palm Springs to Las Vegas led to a process that eventually produced a compromise HCP. Although the San Bruno mountain plan was used as a model, the larger and more densely populated area led the local governments to limit the plan to lizard reserves, rather than imposing restrictions on developments with the species' habitat. Under the Coachella HCP, about half of the Fish and Wildlife Service's designated critical habitat was targeted for preservation, on the basis of reserve viability rather than population surveys. The lizard reserve was cobbled together from federal, state, and local public land, and from purchases of private land; it is administered by the Fish and Wildlife Service, unlike

2s4 Maura Dolan, Endangered Species Act Battles For Its Own Survival, LA Times AI (Dec 21, 1992).

${ }^{285}$ Friends of Endangered Species, Inc. $v$ Jantzen, 760 F2d 976, 987-88 (9th Cir 1985). 258 Craig Anthony (Tony) Arnold, Conserving Habitats and Building Habitats: The Emerging Impact of the Endangered Species Act on Land Use Development, 10 Stan Envir L J 1, 22-23 (1991).

${ }_{237}$ W.W. Dean \& Associates v City of South San Francisco, $190 \mathrm{Cal}$ App 3d 1368, 236 Cal Rptr 11 (1987) (plan amendment is an administrative act and thus not subject to a referendum).

${ }^{288}$ Bean, Reconciling Conflicts at 61-65 (cited in note 252). 
most other HCPs which are administered by local governments. To finance the acquisition of private land, the county assessed a $\$ 600$ per acre fee on all developable land within the historic lizard habitat. Local funding has become a hallmark of all subsequent HCPs. The attempt to manipulate this harsh unstable environment for biodiversity protection is ambitious, but its success has not yet been demonstrated.

Western Riverside County is home to yet another endangered species, Stephens' Kangaroo Rat. ${ }^{288}$ One of the fastest growing urban areas in the United States, the county quickly adopted a two year interim HCP to allow incidental takings while the biological information to protect the rat's habitat was collected. The ultimate objective of the interim HCP is permanent habitat protection, and the county has developed an ongoing habitat acquisition program. Habitat purchases will be funded by both development fees and a requirement that developers purchase one acre of land within the study areas for every acre of occupied habitat that they develop outside of the study areas. The HCP remains extremely controversial because land in the 79,000 acre study area cannot be altered without a permit, and to date no money has been authorized for habitat acquisition.

\section{B. Second Generation HCPs}

HCPs were primarily created to facilitate single species preservation agreements among developers, local governments and the Fish and Wildlife Service. ${ }^{280}$ Instead, they have evolved into legal levers to force regional planning and cooperative regulation for the simple reason that the Endangered Species Act, in contrast to most other environmental regulation, contains strict substantive standards. Ambitious and controversial regional cooperation efforts are underway in California, Florida, Nevada and Texas which test the limits of the Act.

One of the first Regional Habitation Conservation Plans was developed in the Hill Country near Austin, Texas, after the presence of two listed birds, the black-capped vireo and golden cheeked warbler, led to a typical environmental/development stand-off. Austin initially proposed an extraterritorial land use ordinance, but after state legislation barred this traditional tech-

280 Id at $90-100$.

${ }^{280}$ J.B. Ruhl, Regional Habitat Conservation Planning Under the Endangered Species Act: Pushing the Legal and Practical Limits of Species Protection, 44 Sw L J 1393, 1402-04 (1990). 
nique for habitat preservation, ${ }^{201}$ efforts focused on the use of the ESA to force regional cooperation. ${ }^{262} \mathrm{~A}$ fifteen-member Austin Regional Habitat Conservation Plan committee was formed in late 1988 consisting of developers, environmental groups, and local governments. The initial efforts were plagued with problems. Unclear Fish and Wildlife Service planning guidelines, scientific criticisms of the warbler listing, decisions of major developers to seek individual federal approvals, and breakaway local governments brought the process close to collapse in $1990 .{ }^{263}$

Between 1990 and 1992, the executive committee succeeded in putting together an HCP, renamed the Balcones Canyonlands Conservation Plan; however, the idea of species protection remains especially controversial among Hill Country landowners. ${ }^{264}$ The goal "is to provide to the maximum extent consistent with reasonable economic development, [ ] the long-term protection and enhancement of species of concern in Travis County"26s by the acquisition of 29,000 acres of habitat preserves. The planning area was scaled back from a multi-county region encompassing a large part of the range of the vireo and warbler, to the northern portion of Travis County ${ }^{266}$ - described as "part of a unique region from an ecological standpoint."26z The scaling back was partially offset by the decision to include a number of non-listed flora and fauna, including salamanders, spiders, snails, and the Texabama croton, in the preservation objective. To implement the plan, an "administrative unit" under the Texas Interlocal Cooperation Act ${ }^{288}$ was created.

Environmental protection has been criticized for promoting efficiency at the expense of equity. Modern biodiversity planning seeks to address equity issues by putting people back into the landscape. The Hill Country planning process responded to equity concerns by using both biological and socioeconomic criteria to

\footnotetext{
201 John Gravois, Senate Opposes Efforts by Cities to Save Wildlife, Houston Post A23 (May 5, 1989).

${ }_{263}$ Balcones Canyonlands Conservation Plan, Final Draft 1-1, 1-2, February, 1992. ("Balcones Canyonlands HCP").

${ }^{263}$ Ruhl, $44 \mathrm{SW}$ LJ at 1415-23 (cited in note 260).

204 R.G. Ratcliffe, Modern Range War: Ranchers Battle Environmentalists, The Houston Chronicle 1 (Nov 29, 1992) (the curator of the Texas Memorial Museum and expert on cave species was shot in the leg by a rancher while exploring a cave in Williamson County, Teras).

${ }^{263}$ Balcones Canyonlands HCP at 3-1.

268 Id at 5-6 to 5-7.

267 Id at 6-1 to 6-22.

${ }^{263}$ Tex Rev Civ Stat Ann § 4413(32c) (Vernon 1993).
} 
designate reserves and by giving the latter more weight. Biological criteria push decisonmakers toward the preservation of large closely spaced blocks of habitat; socioeconomic criteria push decisionmakers toward the selection of private parcels with low acquisition costs. ${ }^{26 \theta}$ Reserves in Hill Country were limited to the minimum scientifically defensible area. Such reserves require especially active management. For example, some species such as deer and cow birds must be controlled or eliminated. Only time will tell whether conservation biology is more than "political" science.

This plan may become a core element of a more ambitious biodiversity protection effort underway in the Texas Hill Country. Conservation organizations are working with landowners in a twenty-six county area southwest of Austin to create the Texas Hill Country Bioreserve Project. ${ }^{270}$ The objective is to combine traditional land acquisition and local land use controls with cooperation with ranchers in an effort to find development options and land use stewardship practices that will integrate biodiversity protection with traditional human activities.

California is experimenting with the use of biodiversity to both organize state and local resource and land use planning to avoid candidate species listings, and to implement federal and state mandates once a species is listed. California faces biodiversity problems common to many states, but they are generally more acute because of the unique geography and political culture of the state. California is faced with the problem of intense legal and political pressure to protect biodiversity in undisturbed ecosystems threatened by urban growth. Governor Wilson has responded to this pressure by signing a historic Memorandum of Understanding between state and federal agencies to create an Executive Council to formulate strategies "to make the maintenance and enhancement of biological diversity a preeminent" state and local planning goal. The legislature also responded to these pressures by passing the Natural Community Conservation Act. ${ }^{271}$ This Act allows federal, state, and local governments to adopt Natural Community Conservation Plans (NCCPs).

${ }^{269}$ Balcones Canyonlands $H C P$ at 7-9.

${ }^{270}$ Laurel Shaper Walters, Lone Star State Creates Conservation Partnership, The Christian Science Monitor 10 (Aug 20, 1992).

${ }^{271} 1991$ Cal Legis Serv ch 765 (West), codified at Cal Fish \& Game Code $\$$ 2800-2840 (West Supp 1993). See also Fred P. Bosselman, Planning to Prevent Species Endangerment, Land Use Law \& Zoning Digest 3 (Mar 1992). 
NCCPs serve a broader function than federal HCPs. Once an NCCP is approved by the state Department of Fish and Game, the Department may authorize local development approvals which will take candidate species. ${ }^{272}$ The five major southern California counties, but principally Orange and San Diego Counties, are trying to implement the Act to balance rapid development against the protection of the remaining coastal sage scrub ecosystem and the habitats of two birds (the California gnatcatcher and the cactus wren), and the orange-throated whiptail lizard. A Scientific Review Panel has been formed to develop conservation guidelines for a multicounty area of the coastal sage scrub ecosystem, and the Panel is expected to issue its guidelines by mid-1993. The Act provides no authorization for land acquisition and makes private participation discretionary, but the effort has had considerable preliminary success due to the current economic downturn and the presence of large public and private landowners in the planning area. At the end of 1992, thirty-one local jurisdictions and thirty-seven private landowners had enrolled over one million acres in the Coastal Sage Scrub NCCP program. ${ }^{273}$

Enrollment is a voluntary interim agreement not to develop land pending surveys and the publication of conservation guidelines. Once land is enrolled in the program, it cannot be developed (except for public safety reasons) and it may be surveyed by the Scientific Review Panel. The efforts have been helped by the enrollment of 210,000 acres of military land in San Diego County, and by the decision of the Irvine Land Company to dedicate 17,000 acres of land in Orange County as biodiversity reserve. After the Scientific Review Panel publishes its initial survey data and guidelines, a more precise biodiversity management strategy will be formulated which will serve as a guideline for future development and management decisions. California's experiment assumed national prominence in early 1993 when the Secretary of the Interior adopted the coastal sage scrub ecosystem preservation program as the model for reconciling all endangered species and traditional commodity production land uses. ${ }^{274}$ In late March of 1993, the Sec-

272 Cal Fish \& Game Code $\S 2830$.

273 State of California Department of Fish and Game, Report on the Status of the Natural Communities Conservation Planning Program, 1991-1992 I (on file with U Chi L Rev).

274 In February, 1993, Secretary Babbitt identified the creation of a National Biological Survey, which would map the country's biodiversity, as an "imperative objective." Bruce Babbitt, Address to the Environmental Grantmakers Association, Federal News Service (Feb 25, 1993). In subsequent interviews and appearances before congressional committees, the Secretary identified the coastal sage scrub preservation plan as the most interesting 
retary embraced the program and the government-developer-environmentalist negotiations behind it by issuing a special rule under $\S 4(\mathrm{~d})$ of the ESA. The rule lists the California gnatcatcher as threatened rather than endangered, designates no critical habitat, and allows incidental takings of the bird for activities conducted in accordance with the Natural Community Conservation Plan. Incidental takings are allowed during the preparation of the plan and even after adoption if the Plan is prepared and adopted by the state, the Fish and Wildlife Service concurs that the plan is an acceptable habitat conservation plan, and the total loss of coastal sage scrub is limited to five percent of existing habitat as of March of $1993 .{ }^{275}$

The program is politically attractive because it uses conservation biology to support the premise that not all undeveloped land in the defined ecosystem need be devoted to biodiversity. Thus, commodity uses and biodiversity protection can be reconciled. But, it is also a high-risk political strategy because it embraces a science-based plan not yet formulated by the scientists, let alone translated into effective private and public land use regulations. The plan is expected to take five years to develop.

Immediately prior to Interior's special listing rule, the state issued a seven-page Draft Recommendation for Conservation Strategy ${ }^{278}$ which reflects the accommodation premise. The report concedes that the ecosystem is already almost totally degraded, but optimistically concludes that patches of connected habitats with high biodiversity value can be identified and that "[a] smaller reserve consisting of somewhat less than the current extent of all remnant CSS habitat under an adaptive management regime may have a reasonable chance of maintaining . . . biodiversity in the long term."

effort to avoid species preservation-development conflicts. See Marla Cone, All Eyes Focus on "Model" Panel to Save Ecosystems, Environment: Preserve Builds as Unlikely Alliance Vies to Set Aside Land, LA Times (Orange County ed) A1 (Feb 28, 1993); William K. Stevens, Babbitt to Map Ecosystems Under New Policy to Save Them, NY Times 29 (Mar 14, 1993).

${ }_{27 s}$ See 58 Fed Reg 16756-57 (Mar 30, 1993). See also Robert Reinhold, Tiny Song Bird Poses Big Test of U. S. Environmental Policy, NY Times A1 (Mar 16, 1993), for a summary of the events leading up to the issuance of the special rule.

278 California Department of Fish and Game and California Resources Agency, Southern California Coastal Sage Scrub, National Community Conservation Planning, Draft Recommendation for Conservation Strategy (Mar 26, 1993) (on file with U Chi L Rev). 


\section{CoNCLUSION}

Biodiversity protection is the latest and most challenging of the land use conflicts in the United States following the closing of the frontier. ${ }^{277}$ California and local governments in the Hill Country of Texas have begun ambitious experiments to reverse the focus of species protection and to integrate species protection into both the physical and human landscapes. The Balcones Canyonlands and Coastal Sage Scrub protection processes focus on the ecosystem so as to protect the full range of biodiversity. Biodiversity protection has the potential to bring a new focus to land use planning and to accommodate environmental objectives and development, but it can also be a divisive and ineffective force. ${ }^{278}$

Second generation habitat protection planning seeks to move beyond the development-preservation dichotomy which has made effective land use planning so difficult, using conservation biology to identify where existing or more intensive land use and biodiversity protection are compatible. Local governments can adapt land use regulation programs to this objective, but the regulation of land to preserve biodiversity is precisely the type of regulation that the Supreme Court seems to have targeted for heightened judicial scrutiny. ${ }^{278}$ The challenge of local governments will be to find a new but fair balance between individual prerogatives and a sustainable future.

277 The closing of the public domain to unrestricted entry for homesteading, grazing, and mineral extraction during the conservation era has triggered a number of conflicts between commodity production and regulation, of which endangered species conflicts are only the latest. See E. Louise Peffer, The Closing of the Public Domain: Disposal and Reservation Policies, 1900-1950 (Stanford, 1951); William L. Graf, Wilderness Preservation and the Sagebrush Rebellions (Rowman \& Littlefield, 1990). As this Article has made clear, the regulation of private land use throughout the country generates the same, intense conflicts.

${ }^{278}$ A recent article on landowner-species conflicts in the West observes that " $[t]$ he takings provision has emerged as a critical battleground in the conflict between land development and environmental protection." Florence Williams, Landowners turn the Fifth into Sharp-Pointed Sword, 25 High Country News 1 (Feb 8, 1993).

${ }^{270}$ Professor Sax has masterfully explained Justice Scalia's opinion in Lucas as an anticipatory repudiation of any ecological theory of property. Joseph L. Sax, 45 Stan L Rev at 1433 (cited in note 170). 
